Florida International University FIU Digital Commons

4-10-2002

\title{
Boundary : an exploration of architecture's power to mark a boundary
}

Ramon A. Arbesu

Florida International University

DOI: $10.25148 /$ etd.FI14032333

Follow this and additional works at: https://digitalcommons.fiu.edu/etd

Part of the Architecture Commons

\section{Recommended Citation}

Arbesu, Ramon A., "Boundary : an exploration of architecture's power to mark a boundary" (2002). FIU Electronic Theses and Dissertations. 1345.

https://digitalcommons.fiu.edu/etd/1345

This work is brought to you for free and open access by the University Graduate School at FIU Digital Commons. It has been accepted for inclusion in FIU Electronic Theses and Dissertations by an authorized administrator of FIU Digital Commons. For more information, please contact dcc@fiu.edu. 
FLORIDA INTERNATIONAL UNIVERSITY

Miami, Florida

BOUNDARY:

AN EXPLORATION OF ARCHITECTURE'S POWER TO MARK A BOUNDARY

A thesis submitted in partial fulfillment of the

requirements for the degree of

MASTER OF ARCHITECTURE

by

Ramón A. Arbesú 
To: Dean Juan Antonio Bueno School of Architecture

This thesis, written by Ramón A. Arbesú, and entitled BOUNDARY: AN EXPLORATION OF ARCHITECTURE'S POWER TO MARK A BOUNDARY, having been approved in respect to style and intellectual content, is referred to you for judgment.

We have read this thesis and recommend that it be approved.

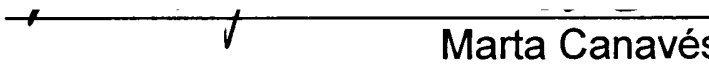

Marta Canavés

Marilys Nepomechie

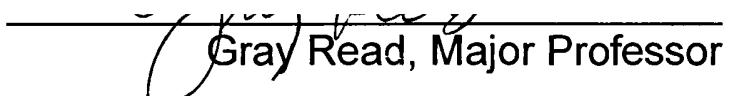

Date of Defense: April 10, 2002

The thesis of Ramón A. Arbesú is approved.

(Dean) Juan Antonio Bueno

School of Architecture

Dean Dougles Wartzok

University Graduate School

Florida International University, 2002 
C C Copyright 2002 by Ramón A. Arbesú

All rights reserved. 
DEDICATION

To my parents and family who have been a source of support and inspiration to me throughout my life. Your encouragement has nurtured my determination to find and realize my potential.

Also, to my love, llú whose affection, understanding and above all, patience throughout the years, enabled me to complete this work with her at my side. 


\section{ACKNOWLEDGMENTS}

I wish to thank the members of my committee for their continued interest, support and guidance throughout the development of this thesis. Marta Canavés' knowledge of the

Everglades and Landscape along with her receptive and supportive guidance facilitated the process. Marilys Nepomechie's knowledge and candor provided the discussions necessary to achieve this works successful completion. Finally, I would like to thank my major professor, Dr. Gray Read for her guidance free from pretense. From its inception, she saw the possibilities and limitations of this exploration as I did and trusted in my ability to achieve our goal. For this, along with her intense interest and time, I thank her. 
ABSTRACT OF THE THESIS

BOUNDARY

AN EXPLORATION OF ARCHITECTURE'S POWER TO MARK A BOUNDARY

by

Ramón A. Arbesú

Florida International University, 2002

Miami, Florida

Professor Gray Read, Major Professor

Cities are no longer recognizing their boundaries beyond their legal or political implications.

This thesis explored the architecture of a boundary in the design of a structure that visually and symbolically marked the current Miami-Dade County development limit along Krome

Avenue. This limit ultimately separates the city from the endangered Everglades ecosystem.

Through the examination of ancient boundaries such as Medieval and Renaissance Military fortifications, as well as contemporary interventions such as Steven Holl's "Edge of the City

Projects", an architectural vocabulary was developed considering the Double Wall, Bastion,

Rampart, and Gate principles. However, rather than considering these principles to defend the

city from outside forces, the focus of this exploration is their inversion in order to contain the

city by strengthening its periphery visually and symbolically.

From this exploration, it was concluded that a successful boundary or limit should be visible and significant. Furthermore, it should serve as an informative and reflective landmark. 
Boundary Precedents

Case Studies

21 Stitch Pattern / Bastion

2.2 Spatial Retaining Bars / Double Wall

2.3 Spiroid Sectors

2.4 Running Fence

Miami vs. Everglades

3.1 Sprawl-A-Development

2

3

6
7

Points to Consider

4.1 Geometric Boundary

4.2 Defensive Boundary

4.3 Referenced Boundary

4.4 Significant Boundary

4.5 Retentive Boundary

Design Process

$5.1 \quad$ United Front

5.2 Height of Boundary

5.3 Matrix/Intervention

The Prominent Belvedere: A Conclusion

Endnotes 
LIST OF FIGURES

FIGURE

Fig. 1 Single Wall/Rampart

Fig. 2 Double Wall

Fig. 3 Bastion

Fig. 4 Map of Cleveland, Ohio

Fig. 5 Plan of Bastion Fortification

Fig. 6 Map of Phoenix, Arizona

Fig. 7 Sketch of Double Masonry Fortification Wall

Fig. 8 Sectional Model of Spatial Retaining Bar

Fig. 9 Plan of Retaining Bars

Fig. 10 Photo Montage of Retaining Bars

Fig. 11 Map of Dallas/Ft. Worth Prairie

Fig. 12 Photo Montage of Spiroid

Fig. 13 Model of Spiroid

Fig. $14 \quad$ Rampart

Fig. 15 Running Fence

Fig. 16 Great Wall of China

Fig. 17 Dredging of Canal in Everglades

Fig. 18 Explosives for Canal in Everglades

Fig. 19-22 Maps of Development of Miami 1896-1930

Fig. 23 Map of Everglades 1900
FIGURE

PAGE

Fig. 24

Map of Everglades 1999

10

Fig. 25 Map of 2010 Urban Expansion Boundary Miami, Florida

11

Fig. 26

Everglades

Fig. 27 Construction of Streets in Miami

Miccosukee Gaming \& Casino Facilities Sign

Concept Model (Static)

Concept Model (Motion)

Fig. 30

View East of Height Analysis (0'-48')

View West of Everglades

View East of Miami

Fig. 36

Ad-Hoc Model Exploration

Fig. 41-41 Modular Model Exploration

Fig. 45-48 Composite Model Exploration

Fig. 49,50

Pin-Connections of Primary Structure

Isometric Section of Single Structural Bay

Images relating to East side of Boundary

Images relating to West side of Boundary

View of Boundary From East

View of Boundary from West

View of Boundary from Below 


\section{Boundary Precedents}

The boundary is a primary element of ancient city form. Whether the city boundary was established prior to or after its founding, it was a sacred occasion. Currently, cities do not recognize or celebrate their boundaries through architectural form. In contrast, Romulus and Remus founded Rome by marking the city boundary with a trench. A bull and cow were yoked to a bronze plough that was dragged around the city's periphery creating a sacred furrow. ${ }^{1}$ The founder raised the plough to create the city gates. Plutarch writes that Romulus killed his brother Remus when Remus jumped over the trench, violating the sacred boundary. ${ }^{2}$ Through the execution of his sibling, Romulus set the example of the solemnity of the urban boundary.

City boundaries or fortifications of Medieval and Renaissance cities enabled a small garrison force to defend the city against more powerful armies. Early cities were often built in sites with natural boundaries such as mountains, rivers, and cliffs that were easy to defend. ${ }^{3}$ In the $17^{\text {th }}$ century, cities were usually developed within multiple concentric rings of defense that rose higher and higher so that soldiers in the outer defenses could be given some protection by those in higher positions behind them. ${ }^{4}$

Towers were used as outlook points for gunnery. Perched high above the walls, they not only added to the stability of the wall, but provided a broad vantage point needed to inform the army and citizens of an approaching invasion. Gates also served important roles in the city's protection. Regulator of entry and departure, the gate system facilitated a toll and customs

barrier, which ultimately controlled the access to and from the city and it's markets. ${ }^{5}$ Location, city walls, towers, and gates are the result not of mythic, but military thinking. The architecture of boundaries controlled the flux of people, money and goods. Through such interventions, the city defended itself from the outside while limited to the perimeter established by these walls.

Contemporary cities no longer define their boundaries architecturally. We no longer need to defend our cities, but protect the natural landscape from encroaching development. It is only through the limits imposed by the government that urban sprawl is temporarily contained. We must reconsider city boundaries architecturally as a means to contain the city's both symbolically and legally, in order to preserve open landscape near urban centers. Cities such as Portland, Oregon have established strong legal limits to growth, but these boundaries remain un-marked architecturally. Miami also has a legal limit to development at Krome Avenue. My thesis project proposes to reinforce this boundary architecturally using a formal typology drawn from ancient city walls. (Fig. 1-3)

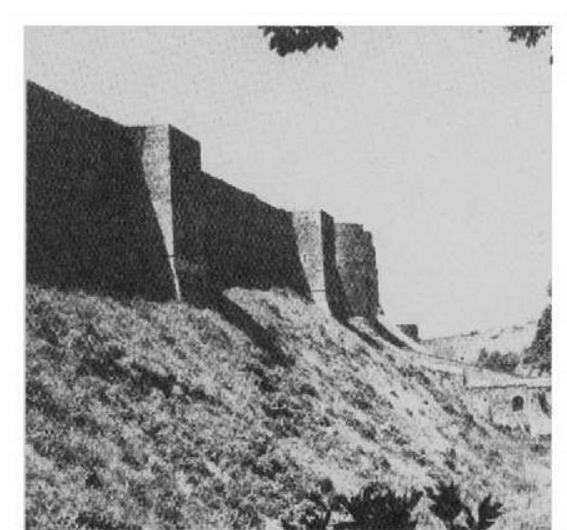

Fig. 1

Single Wall/Rampart

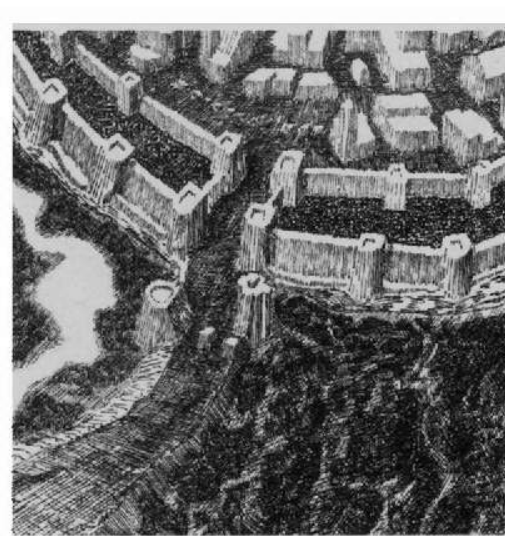

Fig. 2

Double Wall



Fig. 3

Bastion 


\section{Case Studies}

The Edge of a City projects by Steven Holl bear a striking resemblance to ancient forms of typical fortification principles. Contrary to Romulus' city that must be protected from outside forces with a sacred wall only to be trespassed through its gates, Holl's peripheral interventions symbolically protect the natural environment from encroaching suburban development while fostering more efficient communities within

Holl writes that city's grow like the waves caused by a stone tossed into a calm pond. The urban/suburban environment radiates. ${ }^{6}$ The waves closer to the center are more intense and become less intense the further away from the center. This metaphor suggests the high density at city centers and low density at city peripheries. Holl proposes perimeter interventions designed to contain urban expansion. This containment would also foster higher densities of cities through the ricochet of origin vectored development waves. By physically and symbolically limiting the city's expansion, future development is forced inward towards the city's center. Holl's proposals for Cleveland, Phoenix, Rochester, and Dallas address various environmental, social, and physical situations at city perimeters.

\subsection{Stitch Plan}

Holl's proposal for Cleveland, Ohio's city edge, is a series of narrow " $\mathrm{X}$ " patterns or stitches, along the periphery of the urban fabric (Fig. 4). This planar configuration diminishes urban

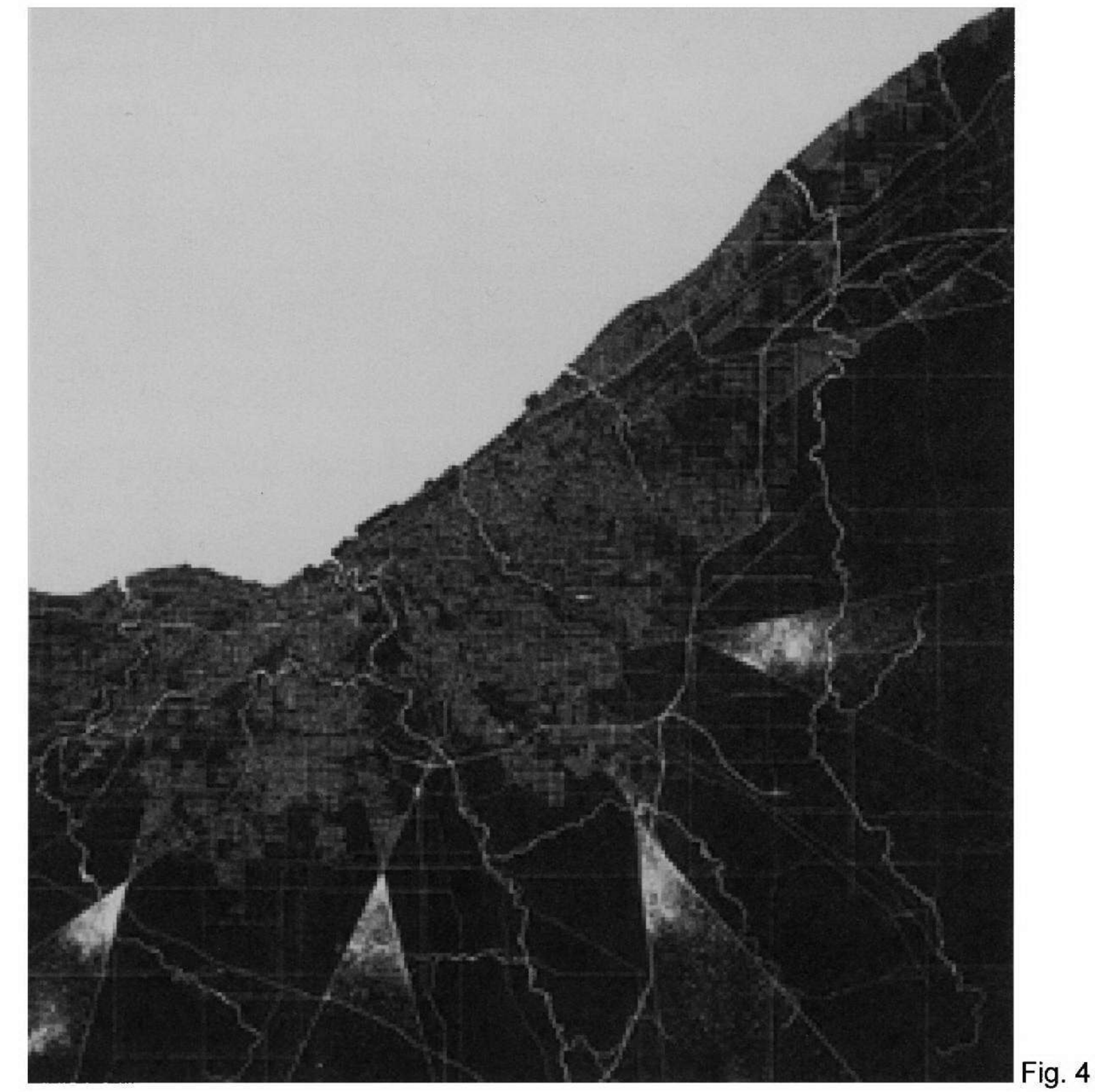

sprawl by confining it to a star shaped pattern that is most concentrated at its points. Holl's stitch pattern is similar to Bastion fortifications common during the Renaissance (Fig. 5) The points of the star are landmarks that mark the transition between development and protected lands. Holl thus adopts a renaissance star shaped bastion but reverses its effect. 


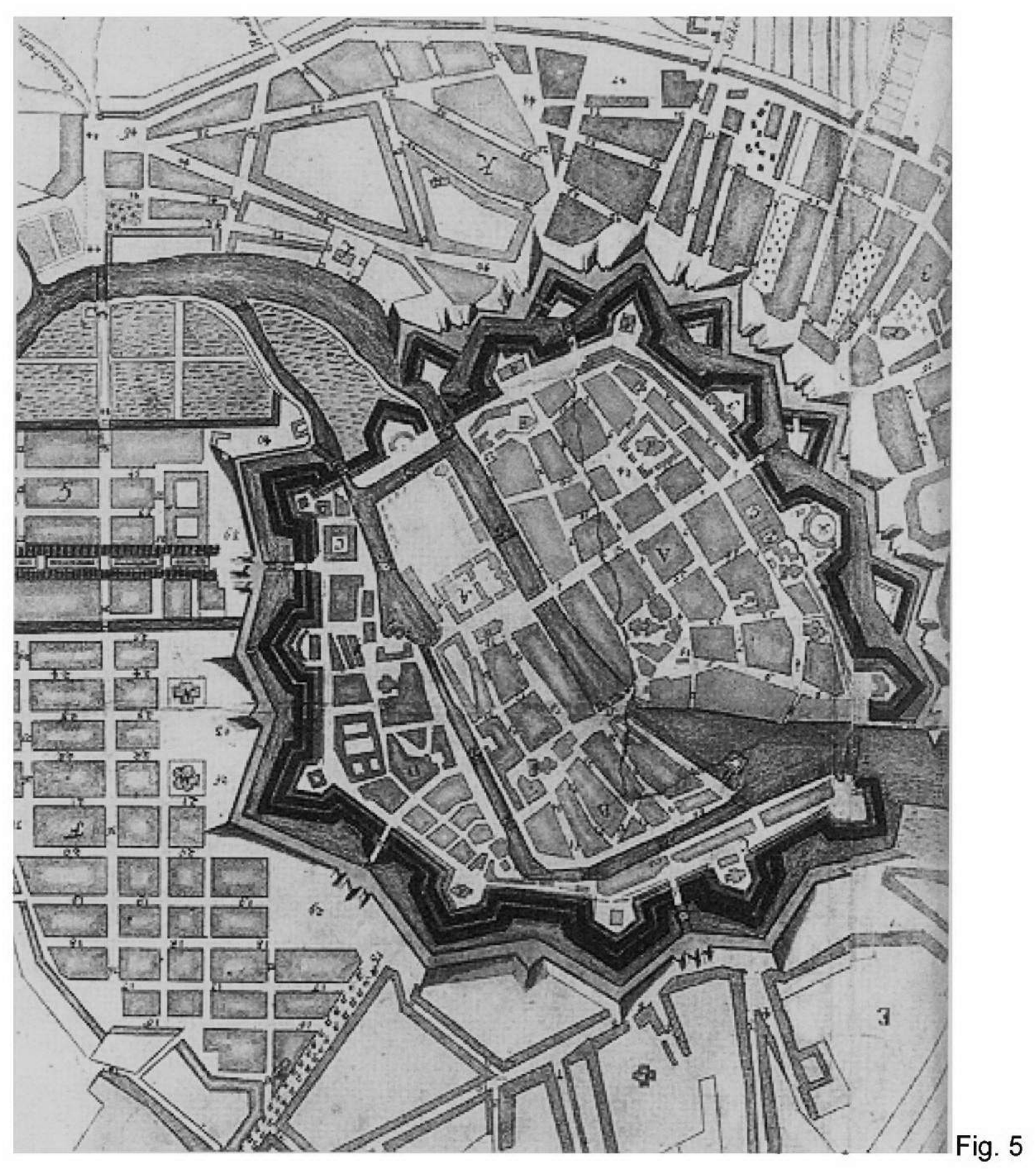

The bastion, an angular fort with triangular sections jutting out from the corners, was a physical defense structure that maximized defense artillery range at its points. Similarly, Holl's stitch pattern is a triangulated, self-terminating pattern marked by architecture rather than artillery, which protects Cleveland's rural region from the invasion of the adjacent suburban development. In addition, its jagged form creates an interlocking urban boundary, which offers a long perimeter so the countryside penetrates deep into the city. This is accomplished not only graphically, but programmatically as well. The intersection of a particular stitch, for example, is a river dam that brings together contrasting urban functions. On the urban side of the intersection are hotels, cinemas, and a gymnasium. On the rural side of the dam are a fish hatchery, aquarium, botanical gardens where people learn about their natural environment. ${ }^{8}$ The dam, a man-made structure designed to control the natural flow and depth of the river, serves as an appropriate mediator between the natural and manmade environments. A dam, in any other location might not carry such connotations; however, in this case, due to its strategic location, mediating the urban/suburban (manmade) and rural (natural) elements of the site serves as a threshold to and from nature.

\subsection{Spatial Retaining Bars}

Holl proposed a series Spatial Retaining Bars in Phoenix, Arizona (Fig. 6). This proposal addresses the disappearance of the 1000-year-old Hohokum tribe of that region. Here, a series of retaining bars create a static barrier to defend sites from the encroaching city. This configuration is reminiscent of yet another fortification wall type: the double-layer masonry wall 
of $14^{\text {th }}$ century Medieval Europe. Masonry fortification walls were often backed up with a second wall for additional defense (Fig.7). ${ }^{9}$ The residual space between was a sheltered belt that could be used by the defenders of the city to stage unexpected sorties (Fig. 8-10). ${ }^{10}$ Much like the other types of fortification walls, the double-layer configuration also consisted of watch towers for lateral support and elevated vantage points.

Through Holl's open structures, views of the mountains and desert are framed. Like the double-layered masonry wall, this boundary is also inhabited. Typically, a boundary only divides, in this case however, the boundary is occupied and ultimately enlarged through the development of habitable space. In Holl's plan, a sense of immediate community is accomplished through the courtyard/sheltered belt configurations of the ground level. In addition, the loft-like living spaces above, provide views of the desert's sunrise and sunset on their respective sides of the boundary. The exteriors are of brightly colored concrete, polished underneath as a hanging apparition of light once reflected by the water of the 250 miles of thirty-foot Hohokum canals. ${ }^{11}$ The proposal of a static barrier and ultimately habitable memorial, to the disappearance of the native Hohokum tribe is appropriate.

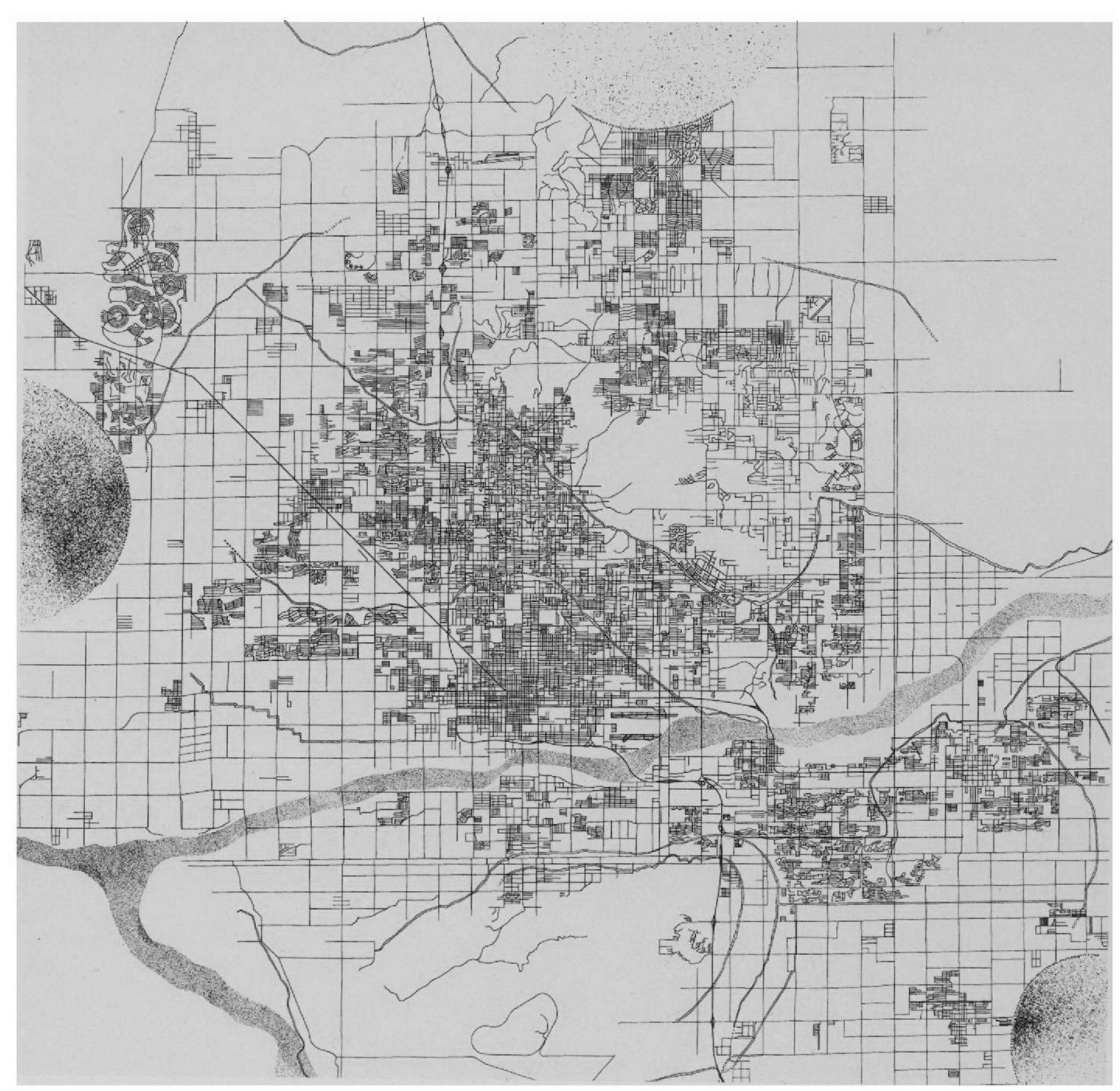

Fig. 6 

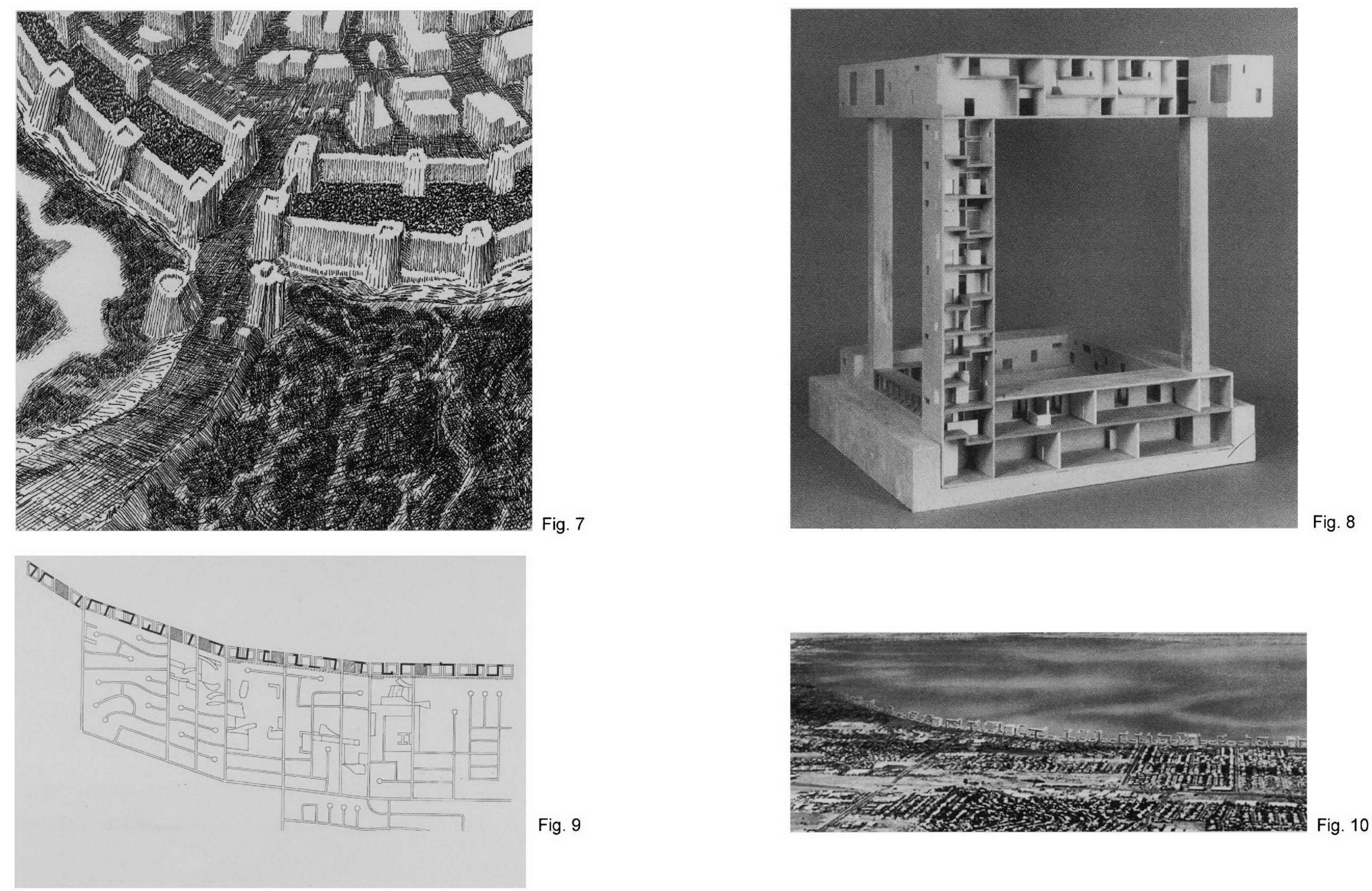


\subsection{Spiroid Sectors}

The framing of protected Texas prairies between Dallas and Ft. Worth is the focus of Holl's Spiroid Sector proposal. These self-contained, hybrid buildings provide condensed living, working, and recreational activities. Formally, the buildings are knotted within themselves resulting in a form that symbolically stops and contains the future lateral development (Fig. 1113). Following the trajectory of development from the suburban area towards the protected prairies, the buildings begin to taper upward and turn in on themselves, culminating in towers. These self-terminating configurations seem to be repelling the otherwise invisible boundary of the endangered prairie while allowing for future growth. This upward shift of form is parallel to the fortification rampart or bulwark (Fig. 14). A rampart is the mass of earth and masonry formed to protect an enclosed area from artillery and small arms fire, and to elevate defenders to a commanding position overlooking the approaches to the fort so created. ${ }^{12}$ Holl's proposal similarly provides an ascending geometry through the creation of these introverted forms.

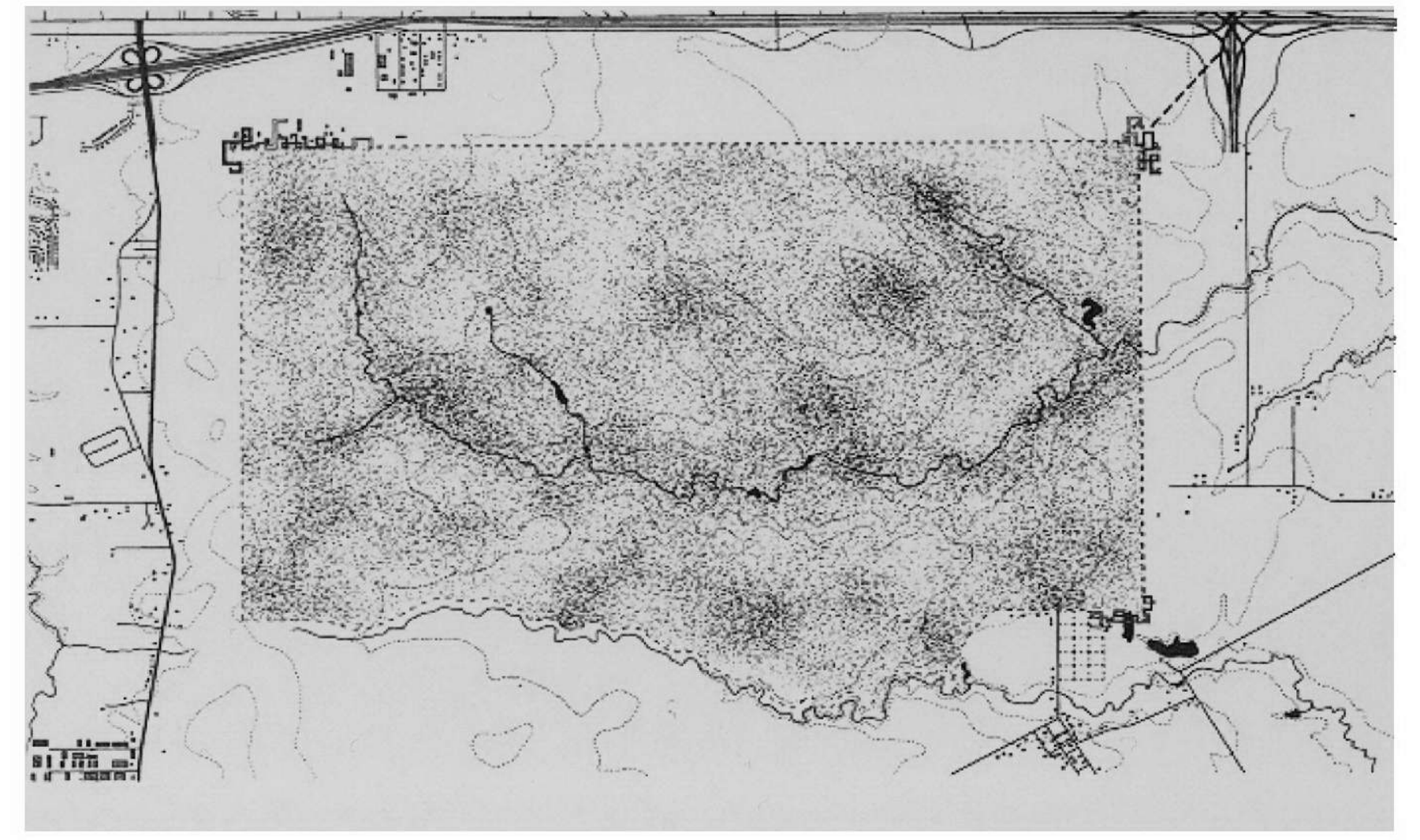

Fig. 11

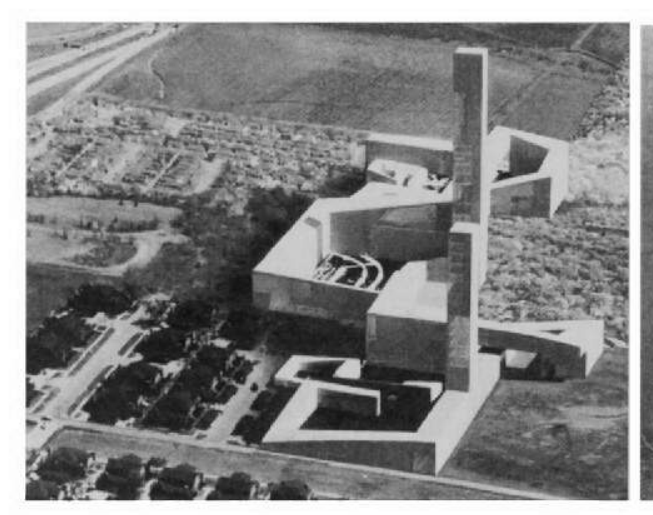

Fig. 12

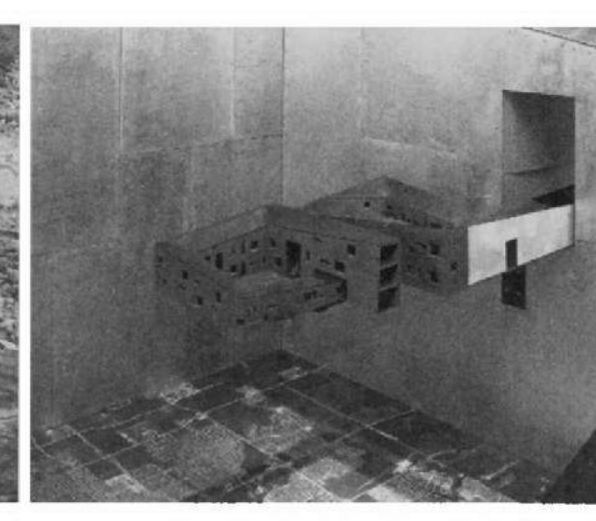

Fig. 13

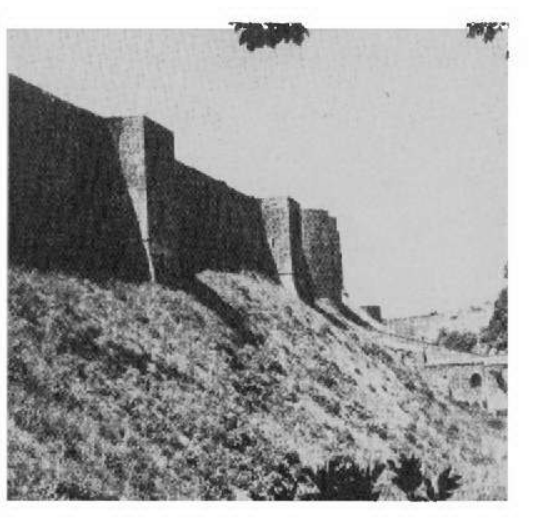

Fig. 14 


\subsection{Running Fence}

The juxtaposition of imposing form in nature is reminiscent of the projects executed by the installation artists Christo and Jean-Claude. Their work, although ephemeral, emphasizes formal qualities in otherwise inconspicuous locations or buildings. One such project is the 1972-76 Running Fence installation of Sonoma and Marin Counties in San Francisco (Fig. 15).

A white nylon fabric fence contrasts the green rolling hills to be seen from San Francisco's Freeway 101. A white ribbon rising and falling into the distance recalls the Great Wall of China (Fig. 16). The curtain, although temporary, draws the spectators attention to the otherwise unseen beauty of the rolling hills or mountains. Christo spent four years, attended 18 hearings, and submitted a 355 page Environmental Impact Report required to build the project for the two week exhibit. ${ }^{15}$ Christo demonstrates that through the responsible insertion of a foreign structure into the environment the beauty of nature can be emphasized.
Fig. 15

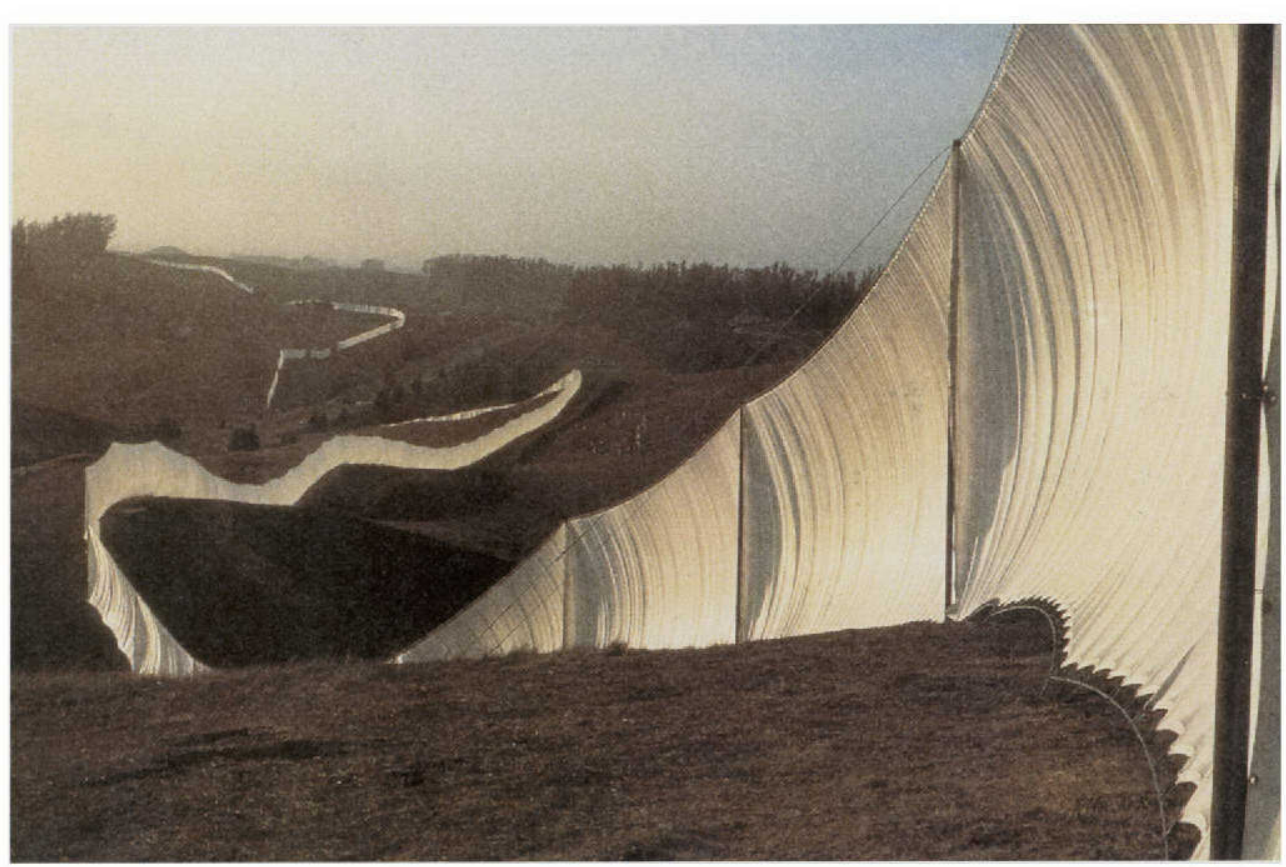

Fig. 16

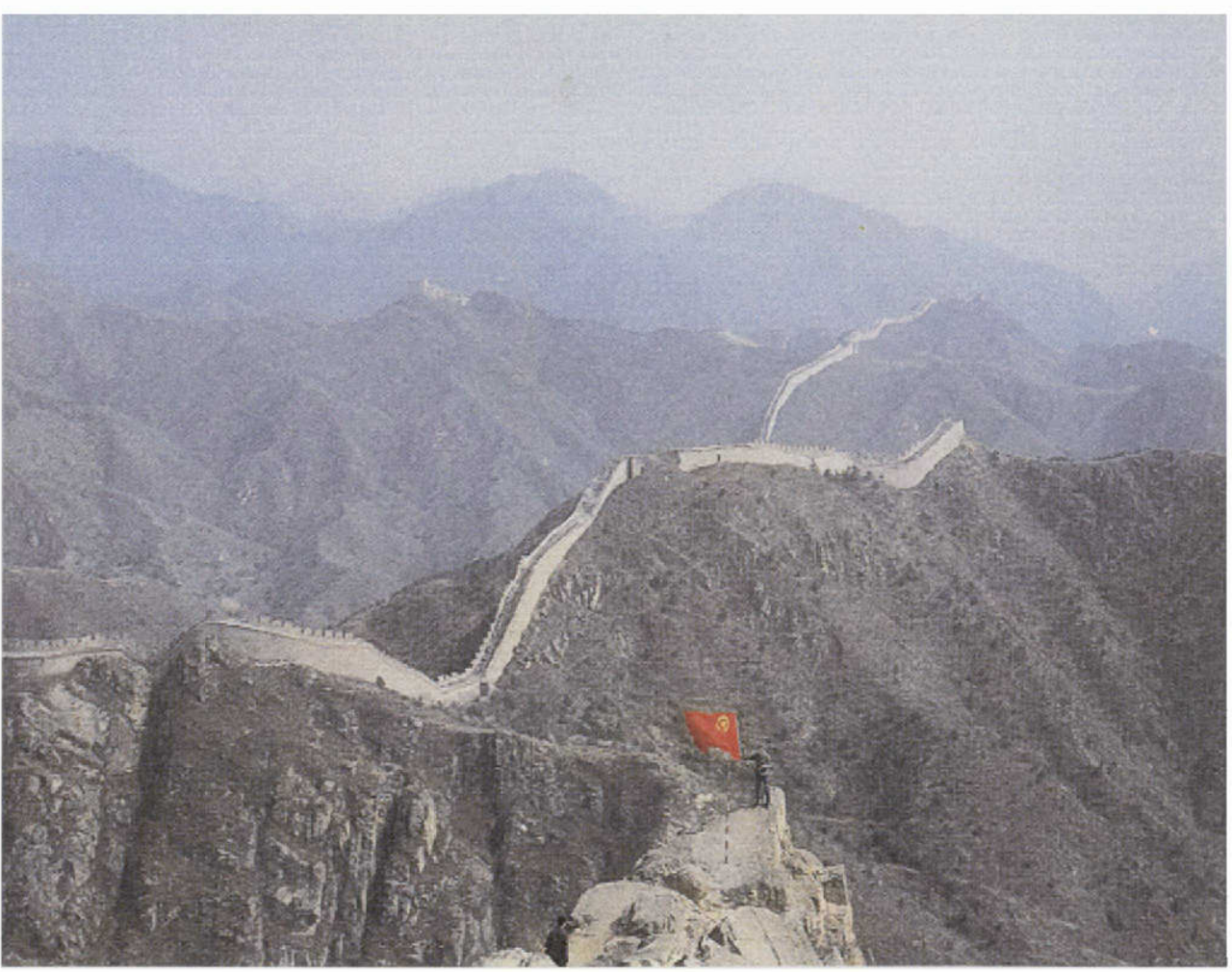




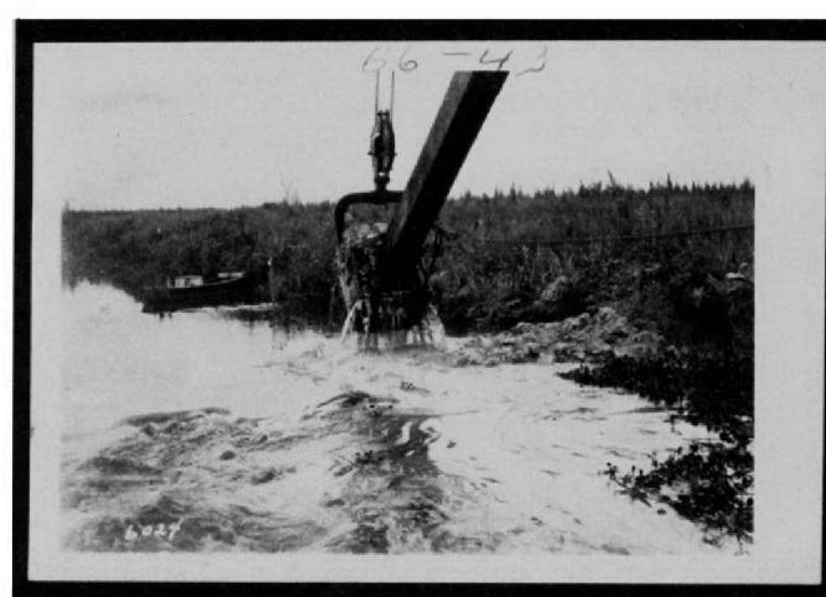

Fig. 17

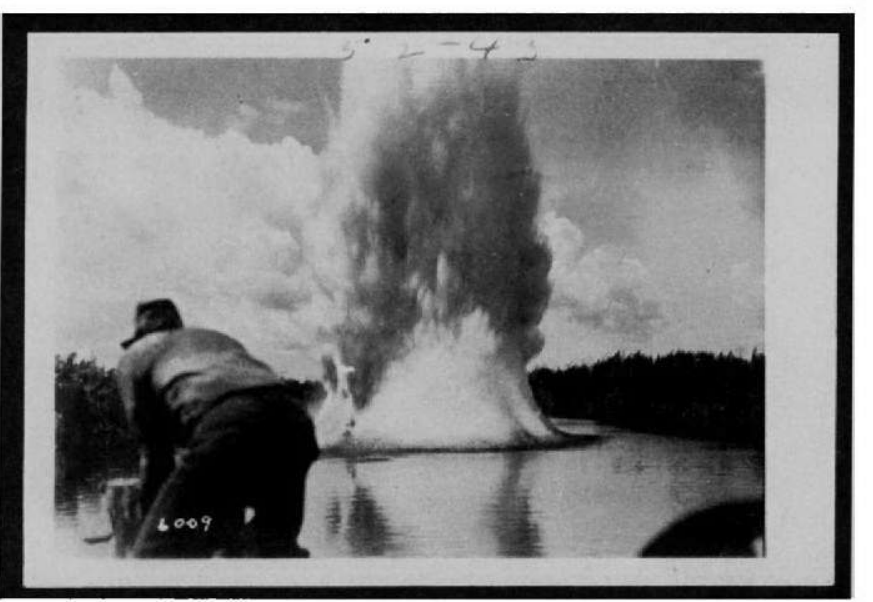

Fig. 18

\section{Miami vs. Everglades}

As the development on Florida's east and west coasts continue to expand toward the middle, the Everglades continue to shrink. In the $20^{\text {th }}$ century, as the American population expanded in South Florida, the developers encroached on the Everglades seeking freshwater and empty land. Developers dug drainage canals without an understanding of the dynamics of the ecosystem (Fig. 17, 18). Expanded dredging efforts between 1905 and 1910 transformed large tracts from wetland to agricultural land. ${ }^{16}$ This abundance of "new" land stimulated the first of several South Florida land booms (Fig. 19-12). Ditching and draining for development since the 1920s has left half of the park dried out and the rest polluted (Fig. 23, 24). Now the numbers of animals within the park are dropping and wading bird nest sites have dropped by more than 50 percent. ${ }^{18}$ Before the encroachment onto the everglades, there were 600 animal and 900 plant species thriving within Everglades National Park but no longer. Now, many species like the American Alligator and Green Turtle are considered endangered. These facts warn of a system and resource under assault and in jeopardy of collapse.

\subsection{Sprawl-A-Development}

Urban Sprawl-A-Development is a pattern characterized by scattered, decentralized, low density development that is not functionally related to adjacent land uses and is swallowing up undeveloped areas in the region at an alarming rate. This pattern results in the depletion of natural and other environmental resources and severely threatens the future viability of the Everglades ecosystem. ${ }^{19}$ Currently, the development of South Florida encourages automobile transport, which exacerbates the lack of coordination in land use decisions. Related consequences of urban sprawl-a-development include competition for scarce water resources, pollution from storm water runoff, inefficient urban design, and rapid conversion of agricultural lands, and other open spaces to urban uses ${ }^{20}$ Preservation of open spaces, including parks and natural areas, would assure adequate storage for water supplies, future recreational opportunities, and continued agricultural productivity.

Suburban development has been a foundation of the American Dream for more than 50 years. But as traffic chokes roadways, taxes rise, open space, and natural resources disappear, there is a growing realization that something must change. As a result, communities throughout the nation are witnessing an increase in the environmental, economic, and social costs of current urban practices. Rapid population growth and sprawl-a-development patterns are leading South Florida, and other regions, down a path toward wall-to-wall suburbanization. 


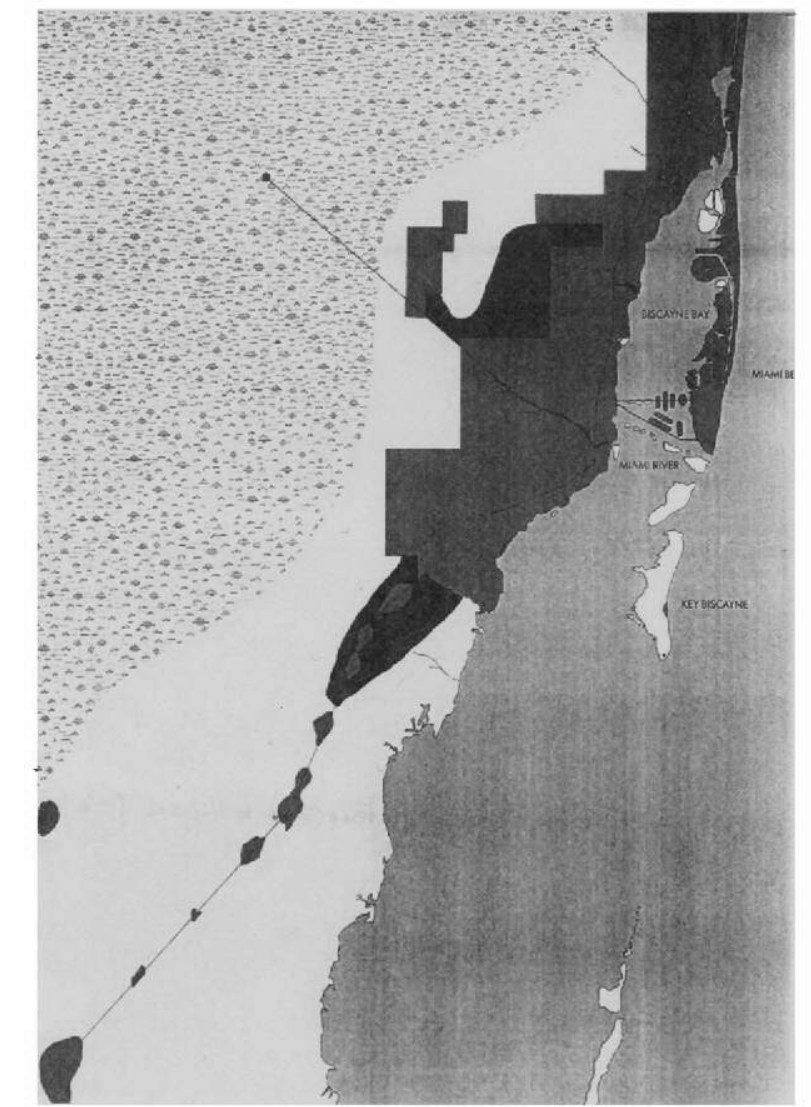

Fig. 22

Miami, 1930s

Great Depression

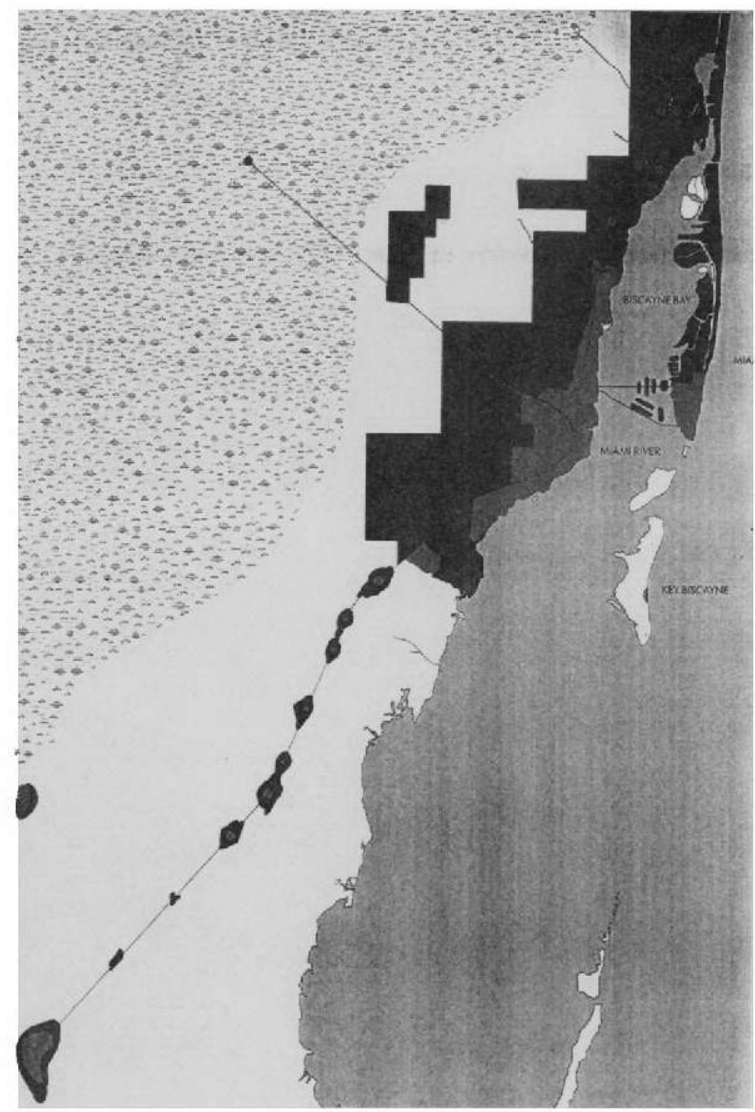

Fig. 21

Miami, 1920-1930

Development Boom

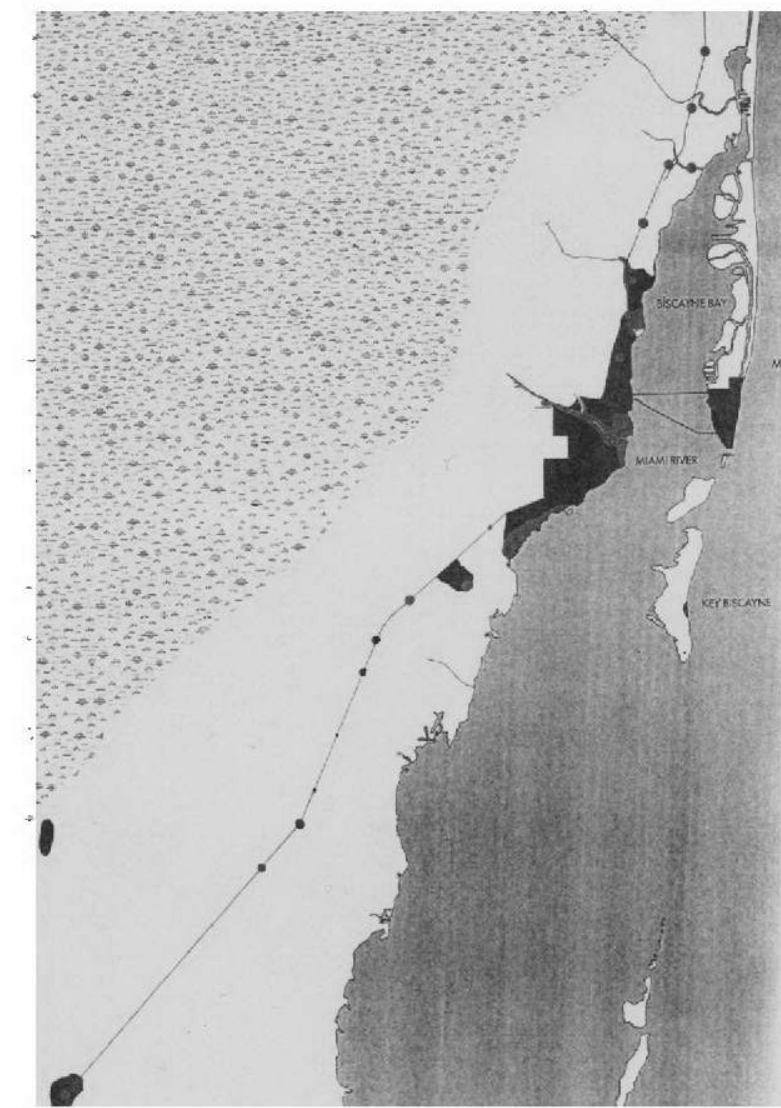

Fig. 20

Miami, 1910-1920,

Beginning of Suburbia

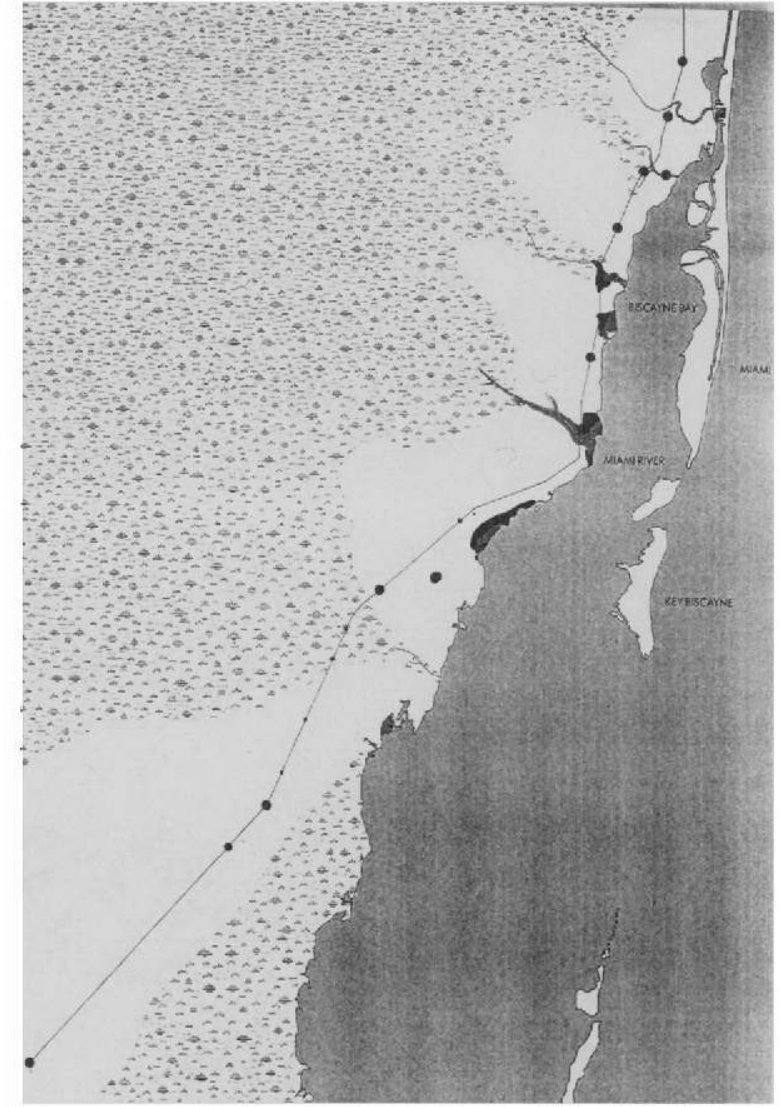

Fig. 19

Miami, 1896-1910

Formative Years 


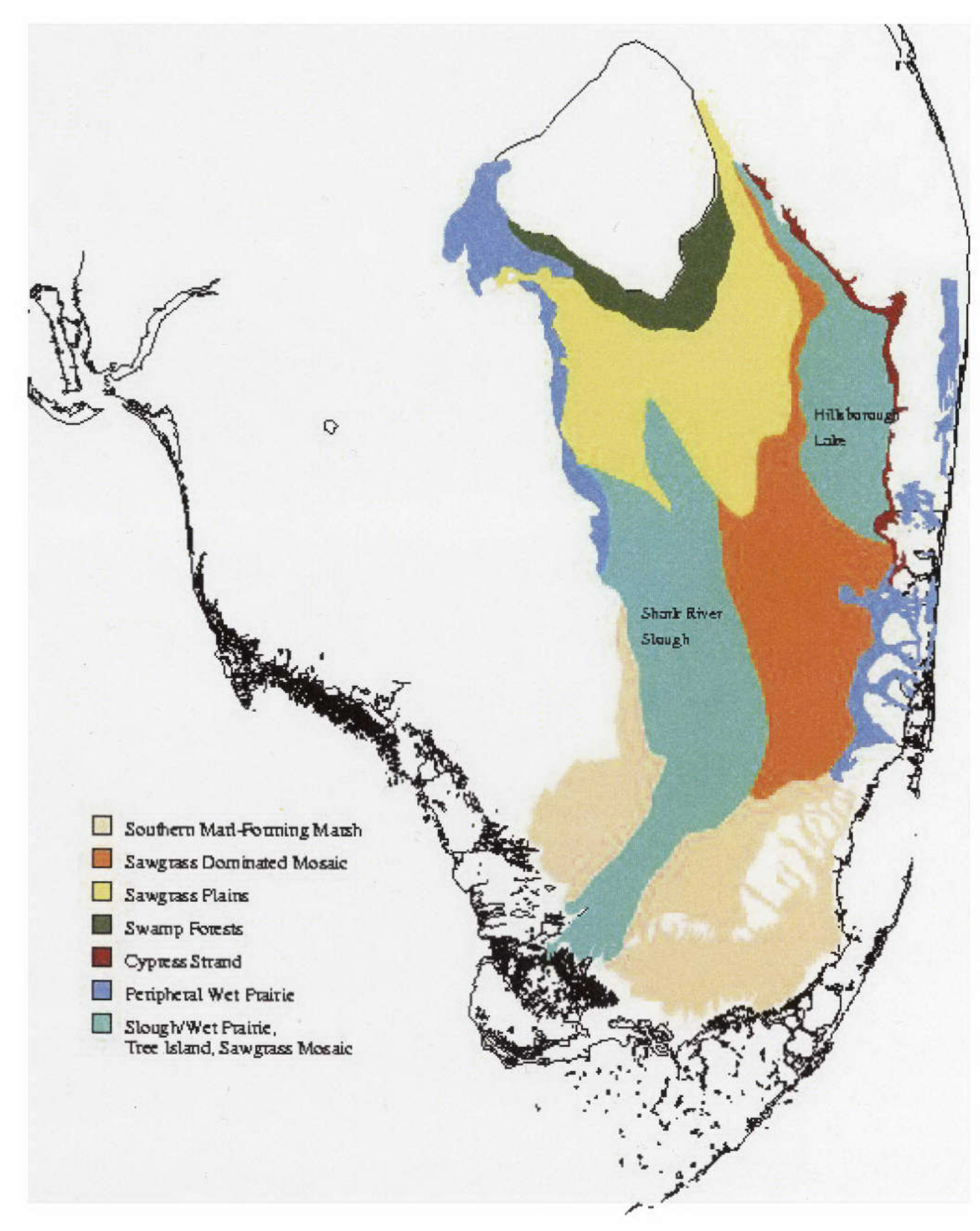

Fig. 23 Everglades circa 1900

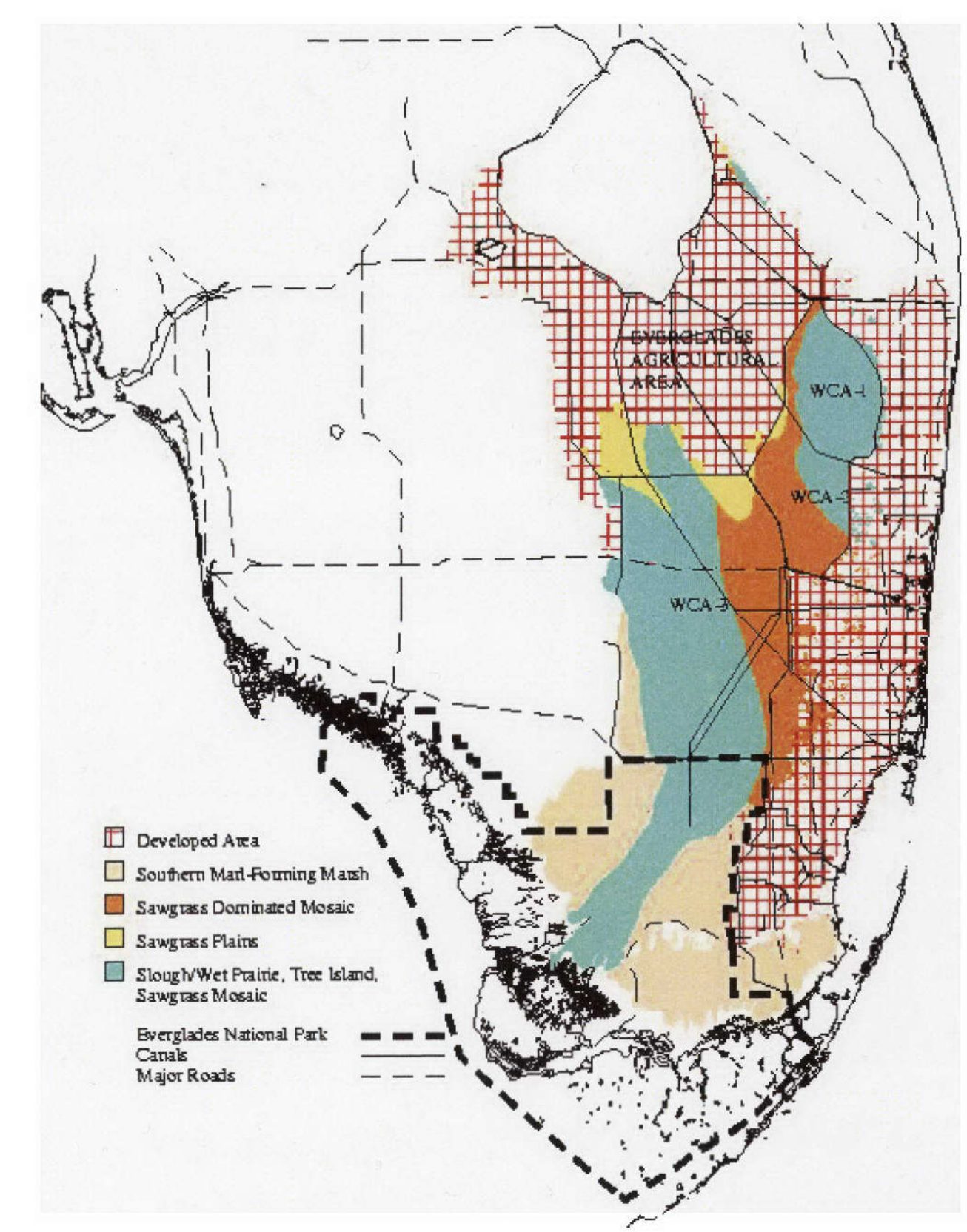

Fig. 24 Everglades circa 1990 


\subsection{Thesis Site}

This thesis project will reinforce development boundaries architecturally using the formal typology of ancient city walls. The proposed site or laboratory for this exploration is to be situated along the threatened western periphery of Miami's District 11 along Krome Avenue (S.W. $177^{\text {th }}$ Avenue). This vehicular artery extends from Broward County to Florida City with few intersections. My site on Krome Avenue is between Tamiami Trail (S.W. $8^{\text {th }}$ Street) and Kendall Drive (S.W. $88^{\text {th }}$ Street). Krome Avenue, within these bounds, is the current MiamiDade Urban Development Boundary (Fig. 25). The immediate area beyond the boundary is host to the Krome Detention Center, Miccossukee Indian Gaming and Bingo Facility, Truck Stop, and Tobacco Trading Post. Like the excommunicated or undesirable activities of ancient cities, people set up camp outside the city walls. The existence of the Krome Detention Center, and Miccosukee Village and Casino outside the boundary, seem to be the contemporaries of the prisons, cemeteries, and gypsy camps of ancient cities. Each of these facilities houses or incorporates populations considered marginal to the urban life of Miami: foreign nationals without immigration status, Native Americans with an independent government that allows gambling, and criminals. A contemporary Krome Avenue raises symbolic and social concerns. It is the limit, that ultimately defines and separates the man-made environment from the natural and Native Miccosukee environment. It is here, the front lines of this metaphoric war that an intervention must be placed Fig. (26-28)

\section{Points to Consider}

Though the densification of urban centers might impede the outward momentum of current suburban development, it is an ephemeral solution to a persistent predicament. The

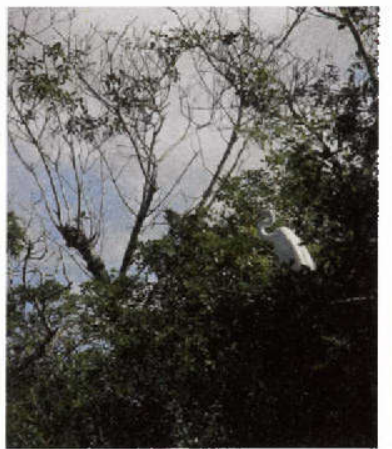

Fig. 26

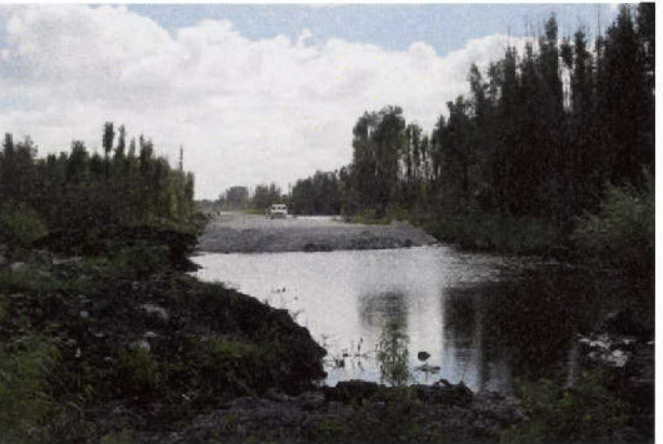

Fig. 27

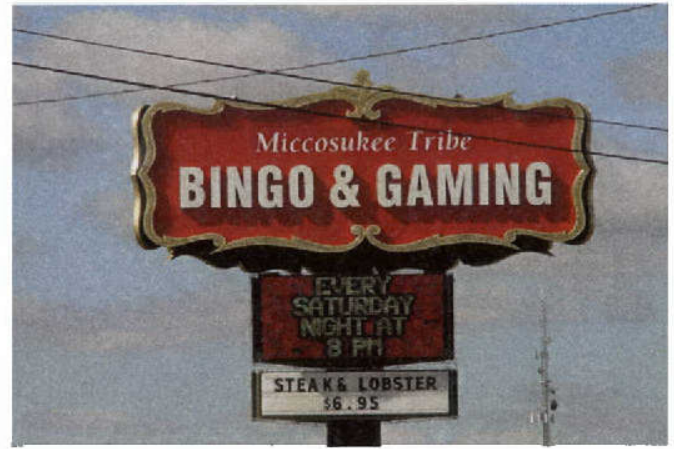

Fig. 28

Fig. 25

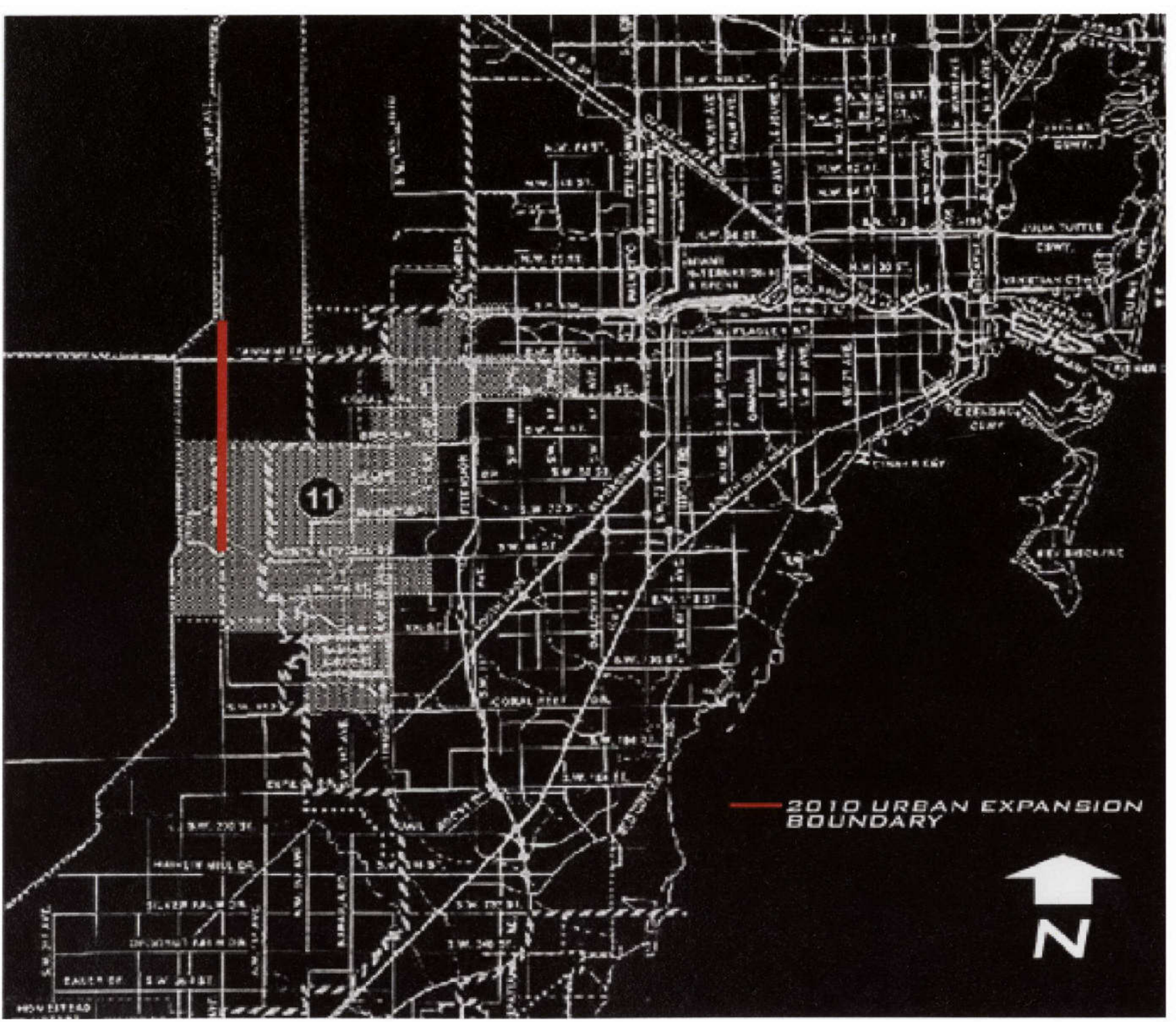


enforcement of Urban Development Boundaries could minimize sprawl and increase density of urban development patterns in Miami. However, it is important to recognize, that an architectural intervention is not capable of stopping the urban expansion; only legal boundaries can. But, through experimental architectural prototypes, the demarcation of such boundaries could make the violation of the boundary a more public and symbolically charged act.

Limiting growth is key to achieving more efficient, livable communities when located and designed appropriately. The periphery where the urban and rural zones collide is the realm in which these boundaries can and should be addressed architecturally. Various architectural principles are to be considered when demarking a city limit.

\subsection{Geometric Boundary}

The Stitch/Bastion pattern discussed in the Cleveland, Ohio intervention expresses the relationship between the natural and man-made environments through a guided, selfterminating, triangular urban geometry. Miami, much like Cleveland and the majority of the nation, is currently developed in an infinite grid. In Miami, streets and avenues propagate indefinitely without any geometric limit. Star-shaped patterns, such as the Bastion, introduce a geometry that imposes limits.

\subsection{Defensive Boundary}

The blunt characteristic of the Bar/Double Wall of the Phoenix, Arizona intervention is also applicable to the Krome Avenue site. The Phoenix proposal was concerned with the disappearance of a native tribe due to the invasive expansion of the city. The Miccossukee Indians of Florida have a similar history. In 1821, when Spain sold Florida to the United States, the Miccosukee were living in settlements near the west coast of Central Florida
During the Indian Wars of the 1850s, they escaped deportation by hiding out in the Everglades. ${ }^{21}$ Present tribal members are descendants of a mere 50 people who eluded capture. There are now about 375 Miccosukee tribal members who live within the Everglades. ${ }^{22}$

Unlike the previous case studies, the Phoenix proposal bluntly marks a city's edge as a sort of monument to the violation of sacred territory.

\subsection{Significant Boundary}

Boundaries are understood through two view-points: of and from.

The perception of is experienced while looking at the structure. In essence, it is the signage or message projected by the boundary onto each of the sides it bisects. Through the appropriate use of form, color, material, and scale to be seen from a distance, a structure can communicate a desired message or gesture related to a boundary

The other, perhaps less considered view-port, is from. This refers to the experience that is perceived from the physical interaction with the boundary. Through strategic occurrences and vistas, one can take from the boundary an understanding that otherwise might not have been possible.

\subsection{Retentive Boundary}

Miami, like many other American cities will continue to grow. The Spiroid/Rampart proposal for the Dallas/Ft. Worth prairie area, primarily addresses the accommodation of future growth while simultaneously limiting the conventional urban sprawl. Understanding that the current Urban Expansion boundary along Krome Avenue is effective until 2010, the possibility of accommodating approaching development should be considered. 


\section{Design Process}

\subsection{United Front}

When analyzing Miami's suburban sprawl at its periphery, it is quite clear that there is no unity in its expansion. This lack of clarity in the boundary's definition causes an amoebic spread that is detrimental to the containment of a city. A conceptual model of proposed project illustrates the idea of a united front. (Fig. 29, 30). A series of six repetitive elements, relating to the six miles of boundary along Krome Avenue, are joined together through the use of a pin connection. This connection allows the individual pieces to swing outward. The pivoted swing is symbolic of the restrain imposed by an intervention which otherwise possesses the ability to expand loosely. Reminiscent of a precise row of synchronized soldiers marching in a parade, which are bound by their choreographed movements, the gravitas of unity in the entity highlights any violations in synchronization. In essence, it expresses the consciously ethical decision to restrain and contain

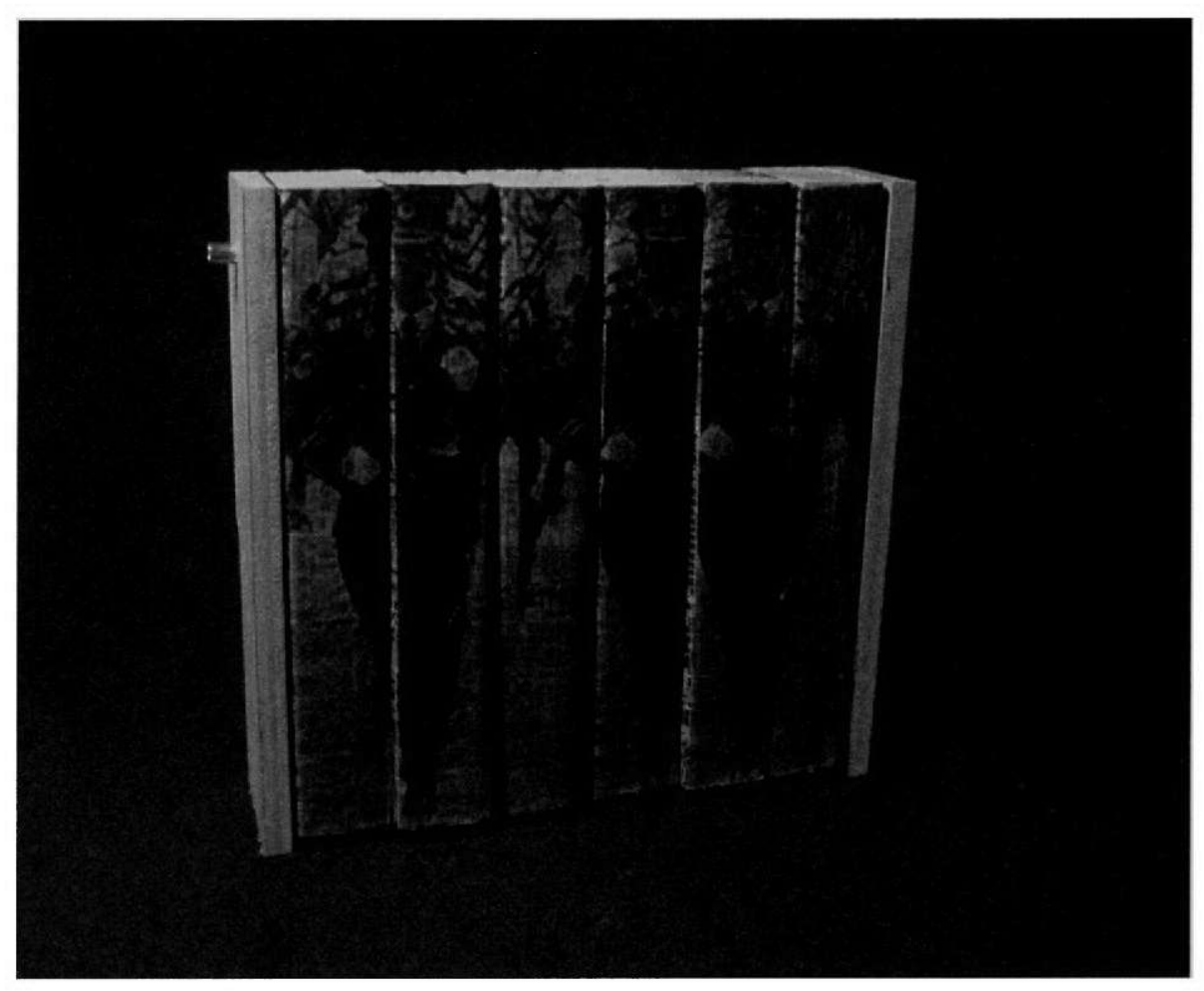

Fig. 29

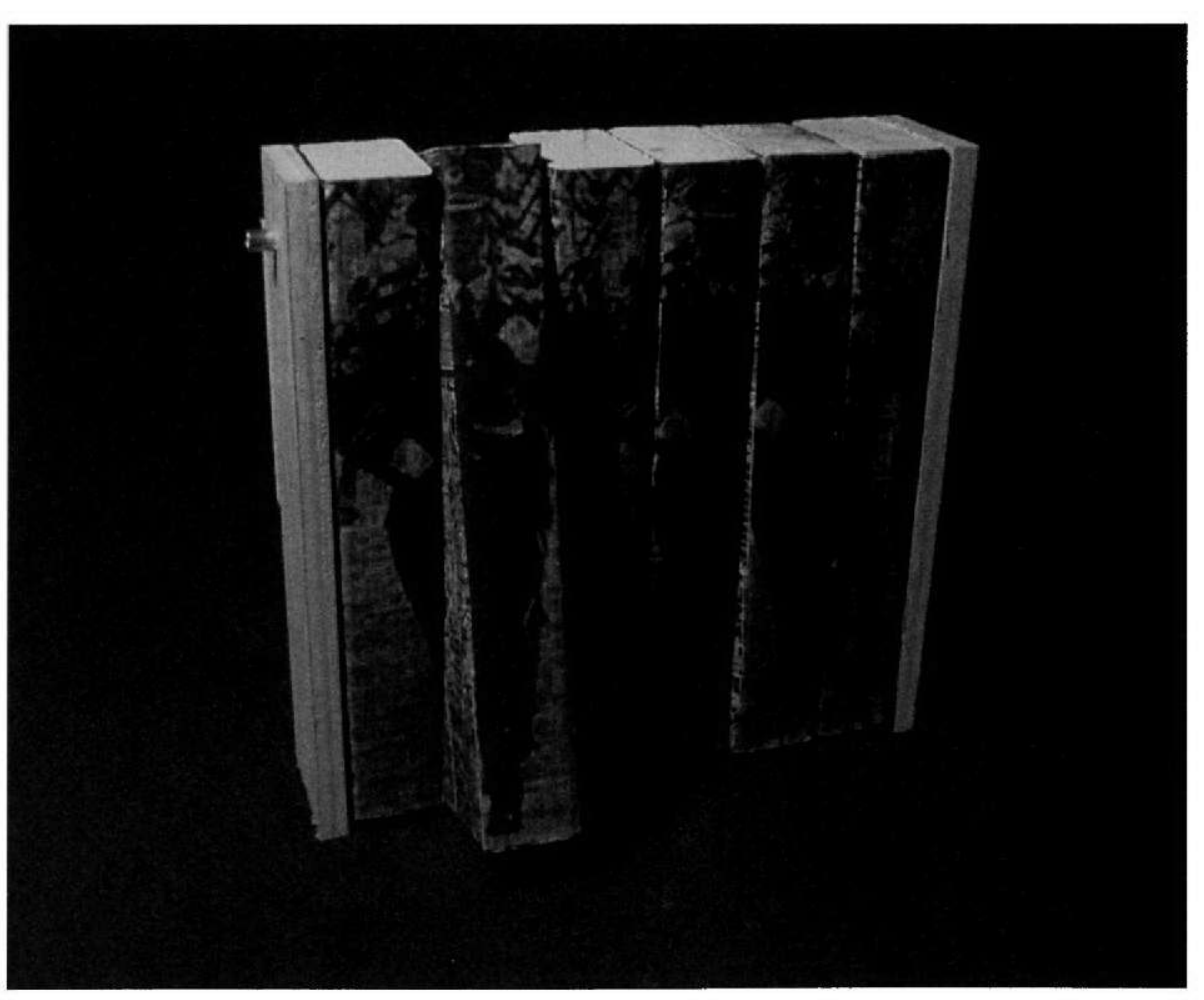




\subsection{Height of Boundary}

Since Miami has mainly developed westward, the portion of the 2010 Urban Expansion boundary situated along Krome Avenue is approximately 18 miles west of the Biscayne Bay edge. In an attempt to get an understanding of this distance, I conducted a height analysis. I took photographs from heights increasing at intervals of approximately twelve feet (Fig. 31-34). Considering that Miami's topography is nearly flat, I found that from a height of approximately 50 feet, one can see the eastern periphery and downtown. This experience is directly related to the from perception previously mentioned. The inefficient low density of Miami's suburban development is made evident from this vantage point.

It also expresses the contrast of the built and unbuilt environments along the boundary's east and west sides respectively (Fig. 35, 36). From an elevated position, one can see both the east and west edges of the city
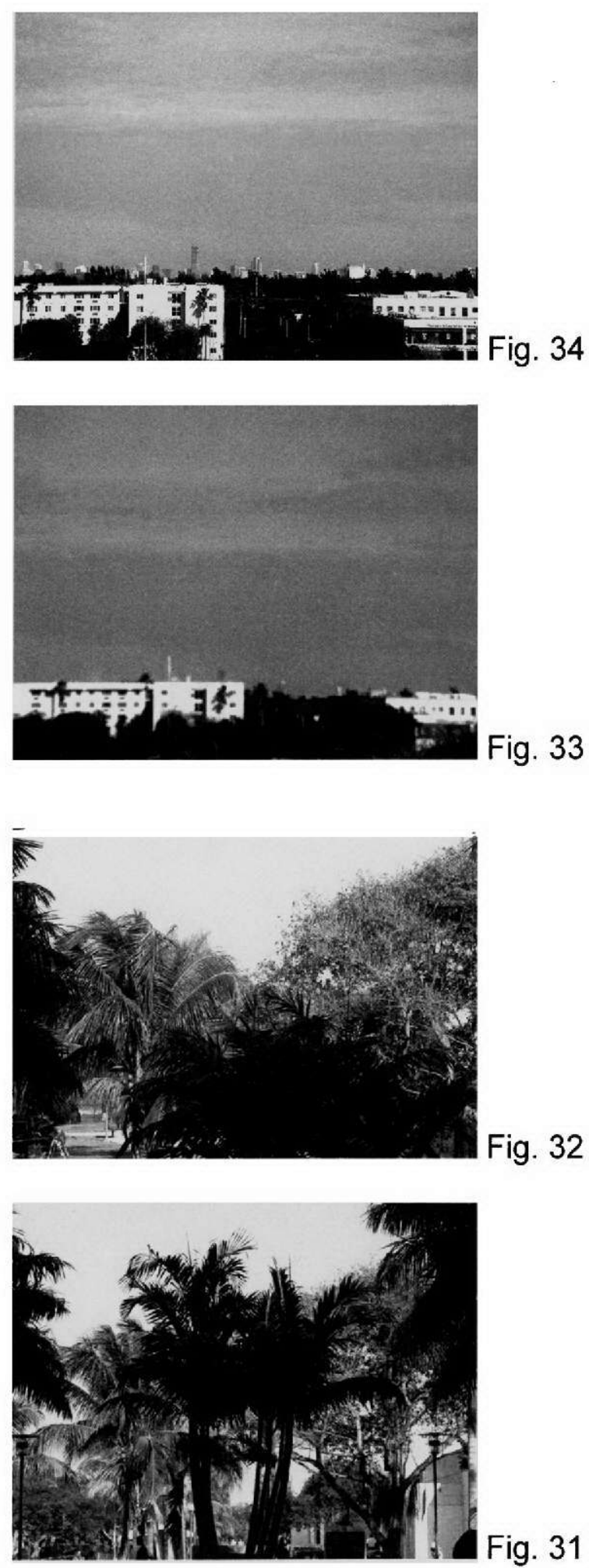


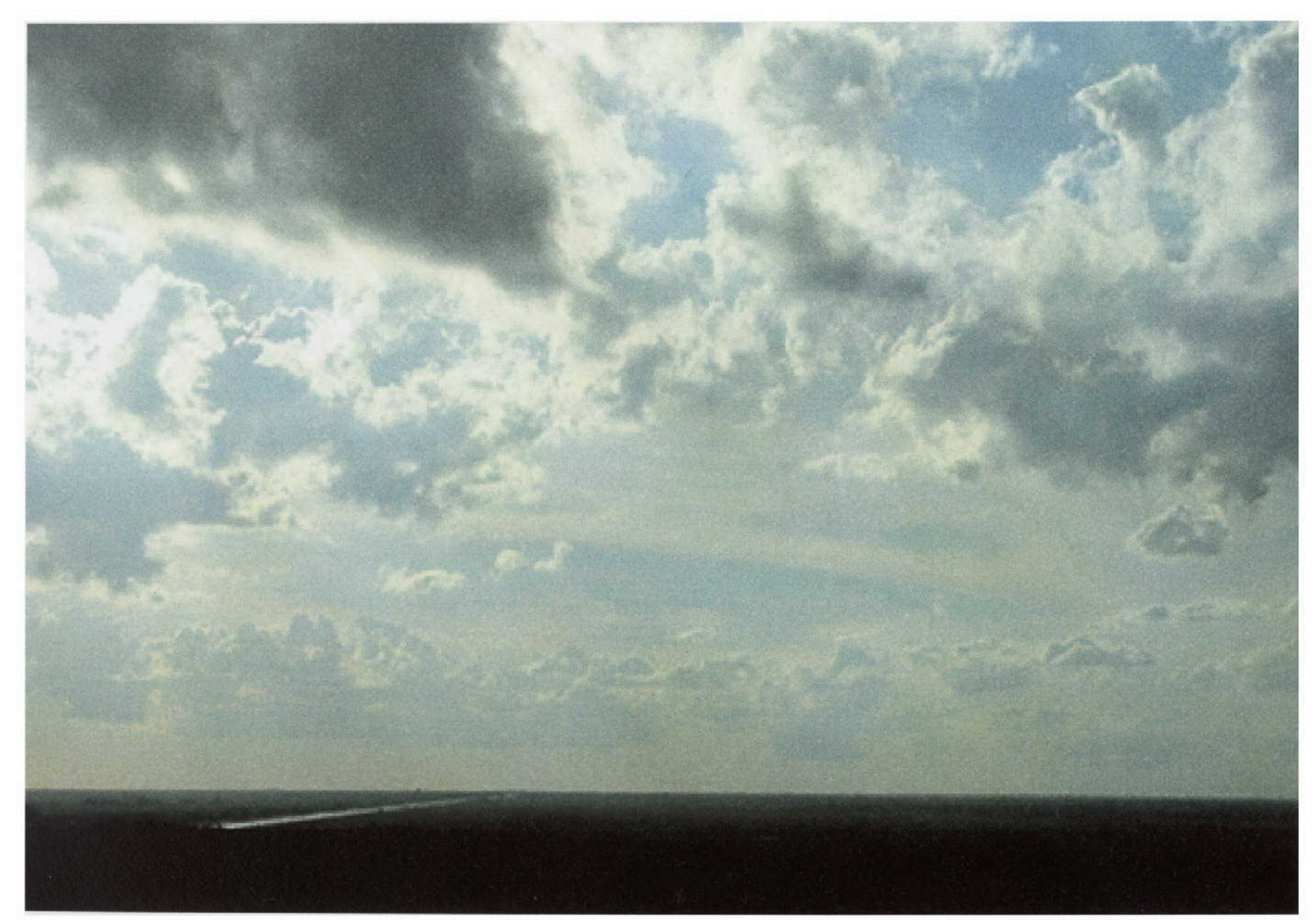

Fig. 35

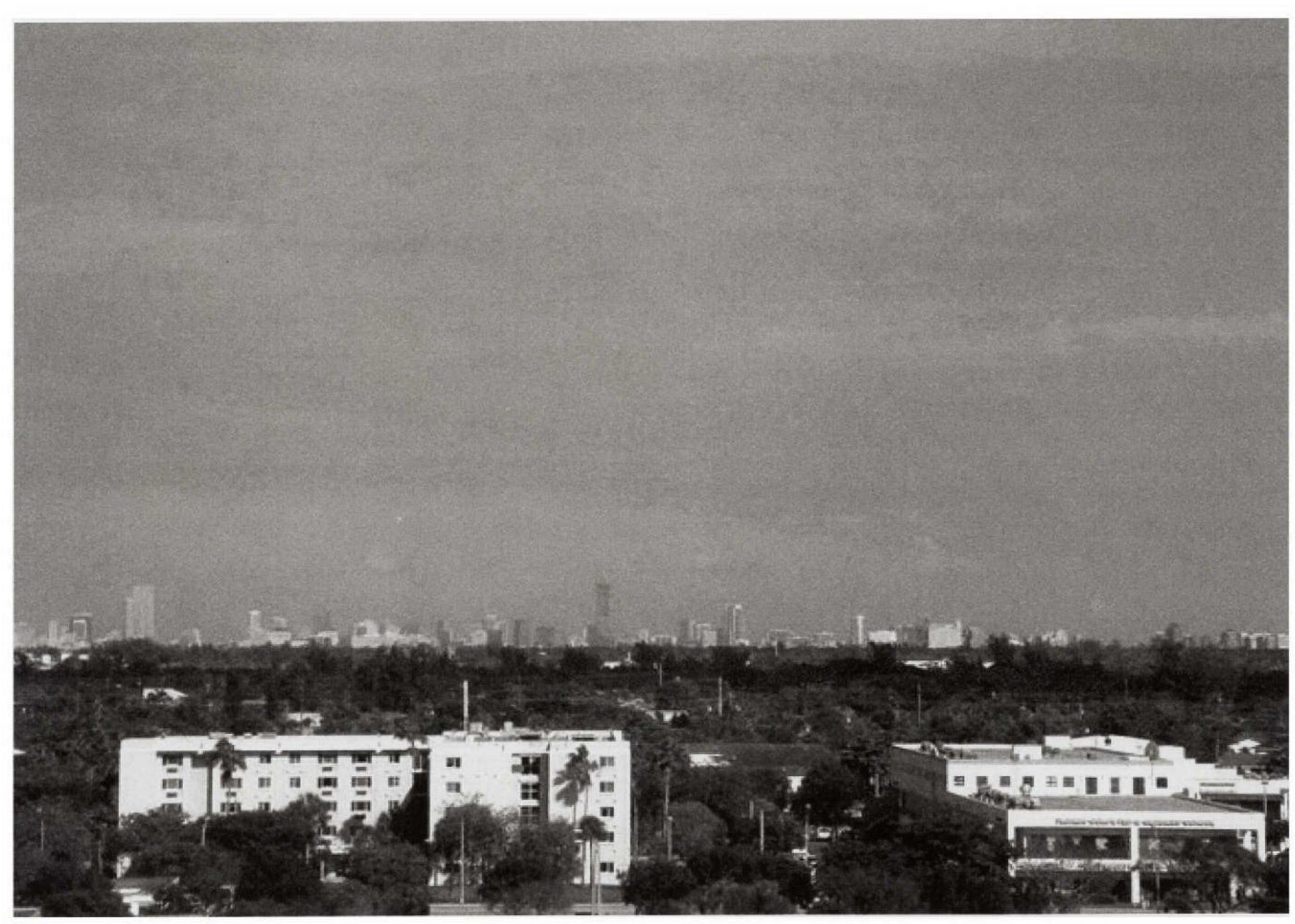

Fig. 36 


\subsection{Matrix/Intervention}

Miami, like all other major cities, is shaped by zoning regulations. These regulations dictate among other things, the use and amount of buildable area, maximum heights, and sometimes the style of construction. This conventional method, which generally focuses on the planar occupation of land, is contrary to the architecture of a boundary whose purpose is to mark. However, understanding that an urban boundary, particularly that of Miami, is sometimes ephemeral, its construction reflects and responds to that quality.

My project will maximize volumetric area to accommodate future growth as well as facilitate relocation with an infrastructural structure. I explored a three-dimensional matrix of steel extending 50 feet high. Rather than regulating the density of an area through lot coverage percentages, floor area ratios and the like, the boundary "site" would consist of a structure designed to support infill construction added over time. Space within the structure would be appropriated or leased, in order for the inhabitant to build upon it in a parasitic fashion. A temporary scaffolding system, as an example for clarification, consists of flexible poles connectors and floor plates, it is designed and constructed to efficiently withstand the weight and movements of a few workers while leaving no evidence of its existence once the task is completed. In addition, the structure can be dismantled and reconstructed at various locations. This method of development, although ephemeral, promotes rapid adaptation and flexibility of a "site."
There are two alternatives to the method of construction within the matrix, Ad-Hoc and Modular. Although both would be based on a pre-determined primary (urban) structural system, designed to support a desired density, the application of the secondary (architectural) structural system would vary greatly between the two.

The Ad-Hoc method would allow for development with any materials. There would be no standard connection or material type. This type of assemblage results in a somewhat, if not totally chaotic guise (Fig. 37-40). The effect would parallel that of objects entangled in a net. With the Modular approach, a standard set of modular pods and connectors would be used as the secondary (architectural) system and inserted into the primary (urban) structural matrix. This type of assemblage would result in a regimented and regular aesthetic (Fig. 41-44). In contrast to the objects caught in the net, this effect would resemble objects carefully and rhythmically inserted into the nets perforations.

The project uses a third method of development, Composite, which borrows the advantageous characteristics of the previous methods. A standardized connection system and kit of parts allows a regimented yet flexible formal vocabulary. In effect, it has objects irregularly, yet more importantly, individually placed in the net (Fig. 45-48). 

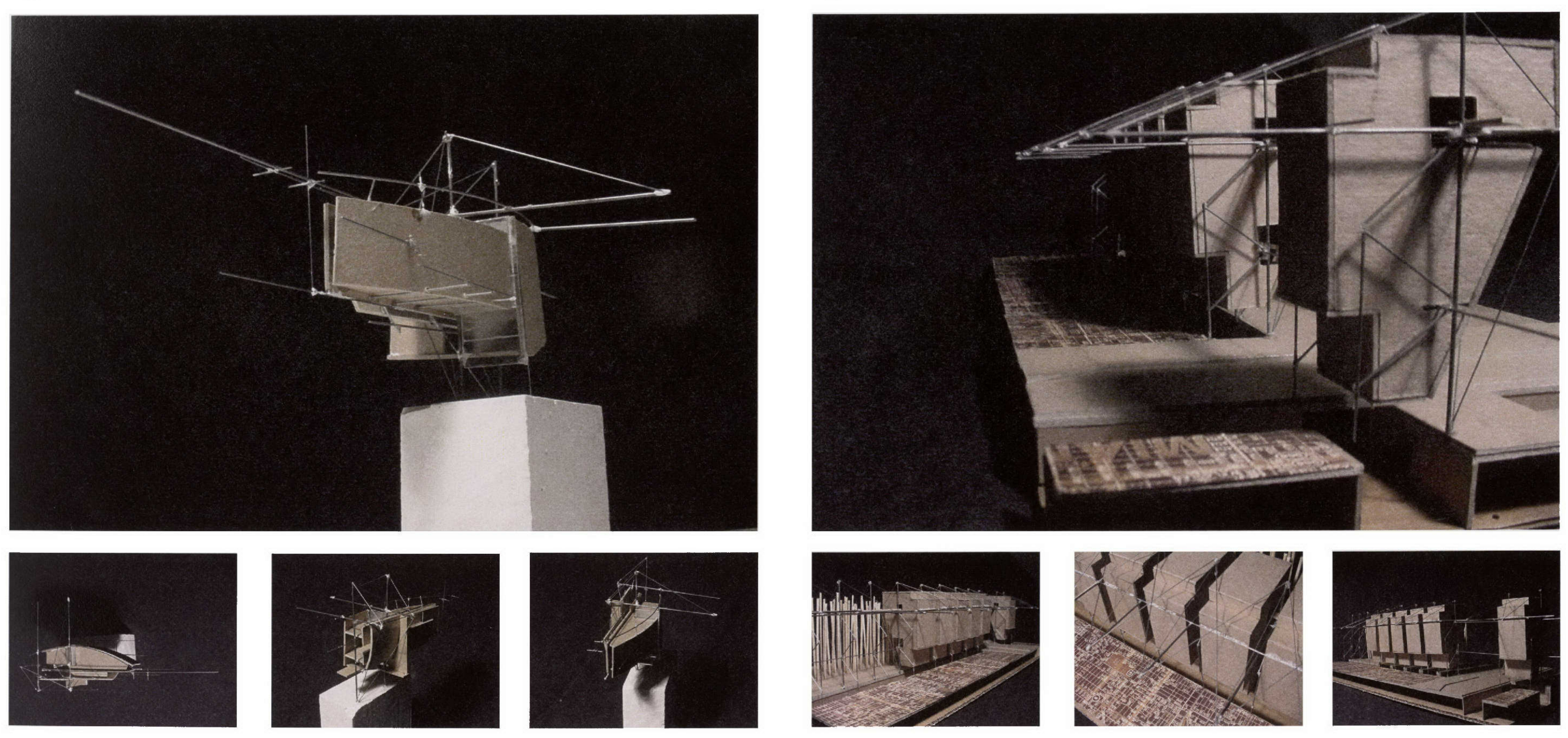

Fig. 38

Fig. 39

Fig. 40

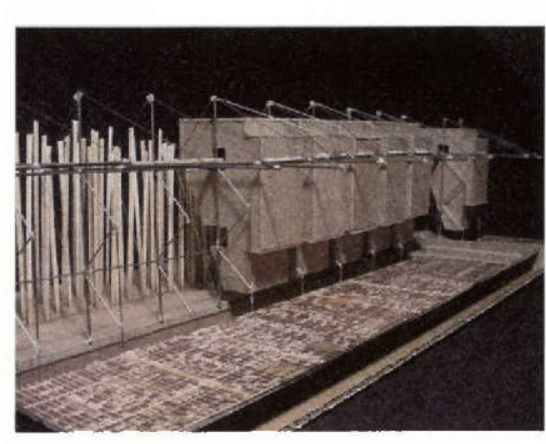

Fig. 42

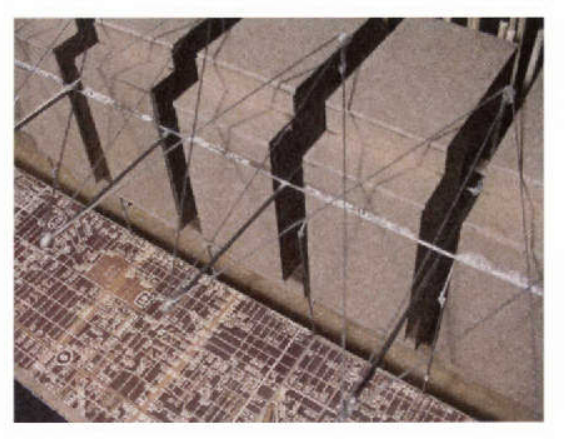

Fig. 43

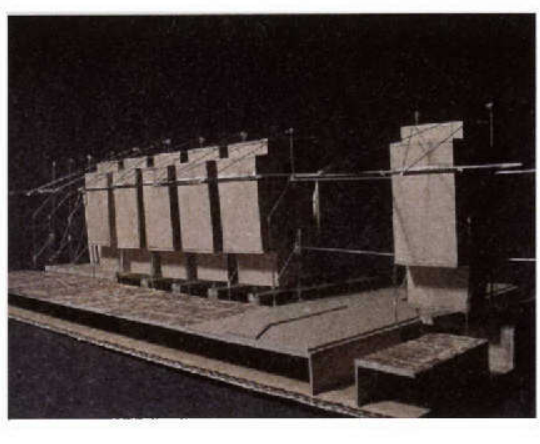

Fig. 44 


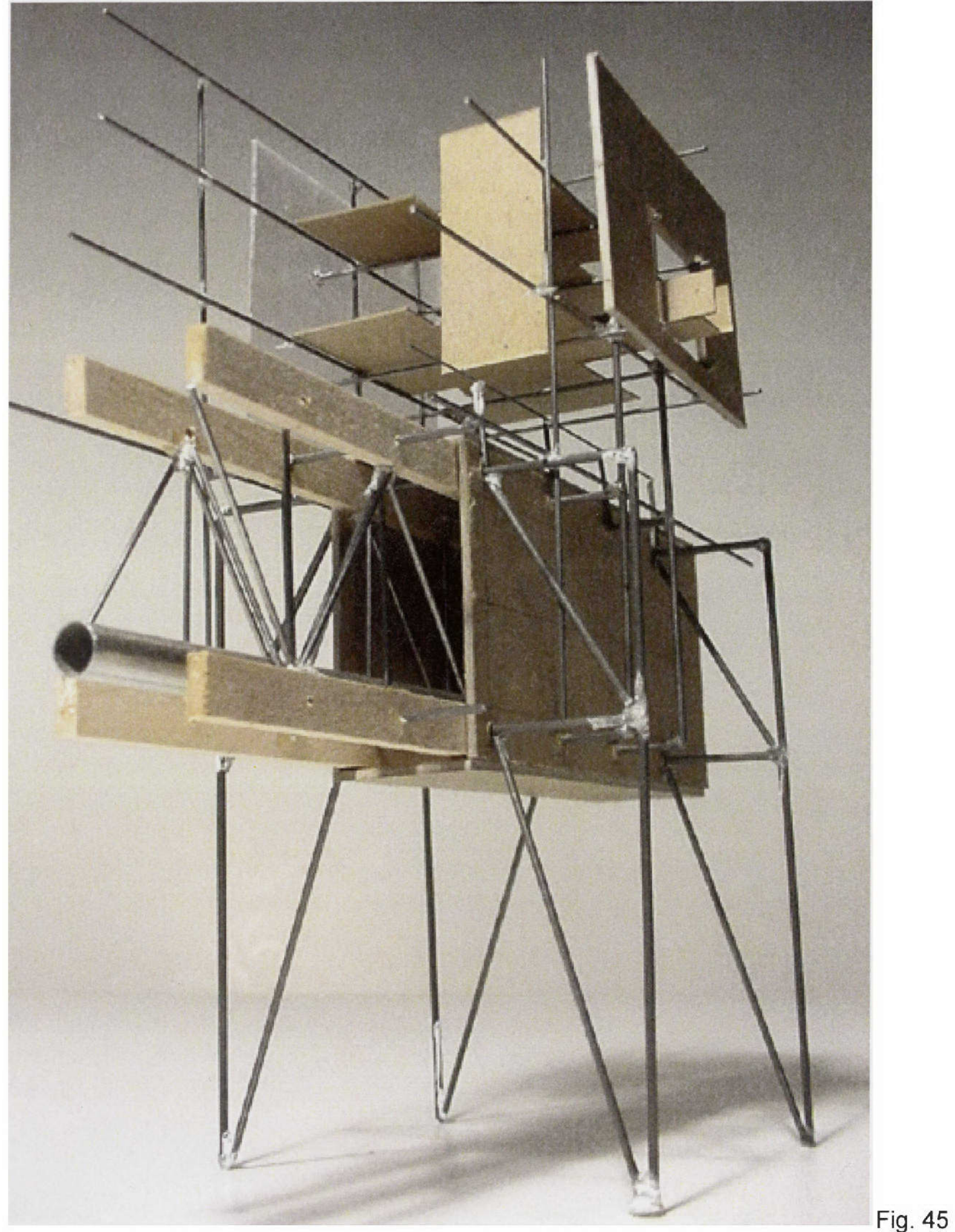

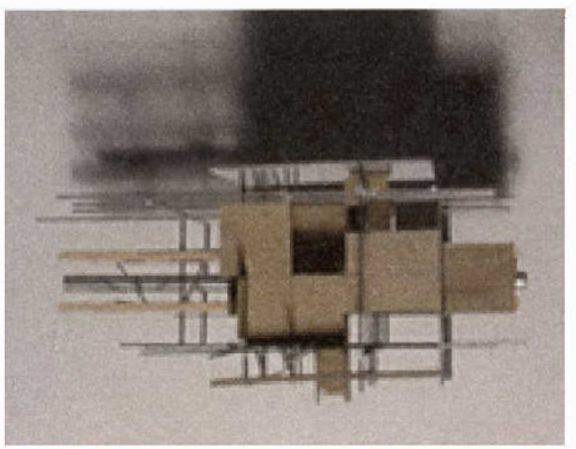

Fig. 46

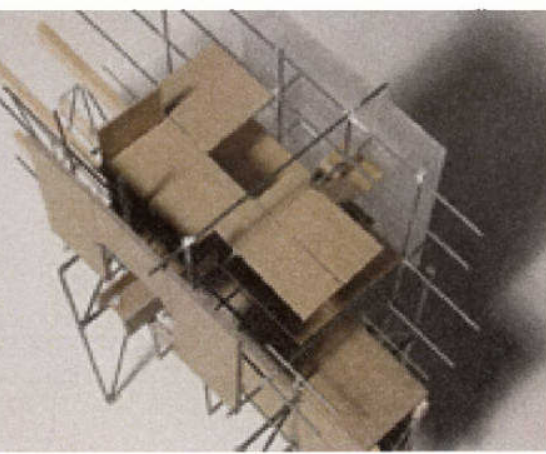

Fig. 47

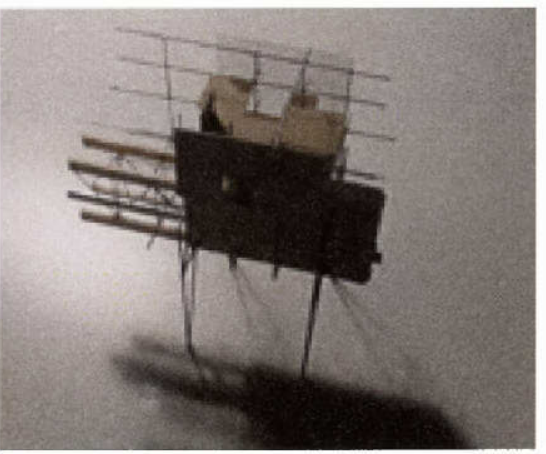

Fig. 48

\section{The Prominent Belvedere}

The final phase of the investigation on the Architecture of Boundary is the culmination of the previously discussed ideas of strengthening a boundary visually and symbolically.

A boundary should primarily mark a limit. In doing so, two physically distinct areas are separated. A monument is created through giving the boundary a thickness. Like a fence, a built boundary makes an invisible limit visible. The resulting intervention uses iconographic references in order to respond to the various conditions pertaining to the site.

Since its incorporation in 1896, Miami's western limit has been moved resulting in an inefficient city more than twenty times its original size. My project addresses the ephemeral nature of this boundary is addressed through the construction method of the structure. However, one can argue that in order to stop development from expanding beyond the boundary one should construct in permanent, fixed modes. The purpose of this exploration is to express the nature of this boundary. Therefore, pin connections of the primary structure allow for the possible dismantling and repositioning of the interchangeable structure (Fig. 49, 50). However, rather than relocating nature, the burden of relocation is transferred onto the proposed boundary 
dwellers. In essence, holding the position and delegations of the boundary accountable for their encroachment onto the Everglades and Micossukee territories. In order to mark and therefore satisfy the view of the boundary, the project is a 55-foot high infrastructural structure, that straddles and is parallel to the boundary. The structure is large so it will be seen from the adjacent suburban development and the city at large. Its height also reveals the infrastructural components of a city such as electrical, water, sanitary, and communication lines (Fig. 51) These otherwise buried components of a city are made visible at the boundary.

The project straddles the canal and contains an elevated public walkway or Belvedere to provide a view from the boundary of the contrasting sides. It provides a vantage point that is reminiscent of the watchtowers and belvederes of historic fortifications. The project not only reinforces the city's western limit, but also serves as a gateway or threshold into and out of the city. This experience of ingress and egress is crucial to the experience of this boundary. The boundary, now physical in nature, responds to the contrasting characteristics of their respective sides. In an attempt to repel and protect the Everglades from the invasive development patterns from the east, formal references are drawn from the stern, austere, and unwelcoming facades of fortification walls through which canons project. The eastern face of the proposed structure is clad in red panels that draw attention and almost completely cover the entire visible façade of the structure (Fig. 52-54). In contrast, the natural environment from the west side is symbolically invited onto the east through translucency. A series of glass panels coupled with a louver system serve as an example of how this might be accomplished (Fig. 55-57).
For centuries, there was a sacred dimension to the building of bridges. Was it because the act of crossing a river or natural boundary suggested a violation? Or because men were fearful, intimidated by the sense of limits reached. A feeling of menace, the threat of imminent catastrophe, the silent and elusive revenge of gods and spirits, or punishment provoked by a world obsessed with defying its limits caused men to see the building of bridges as a sacred act. ${ }^{23}$ Today, the theoretical implication, derived from the mere construction of a bridge or the crossing of an obstructive frontier, a limit imposed by nature, is not given architectural expression. Through scale, form, and iconography, this project informs, contains, educates, protects, and projects its presence as a boundary in hopes of creating a more eloquent and efficient city. 

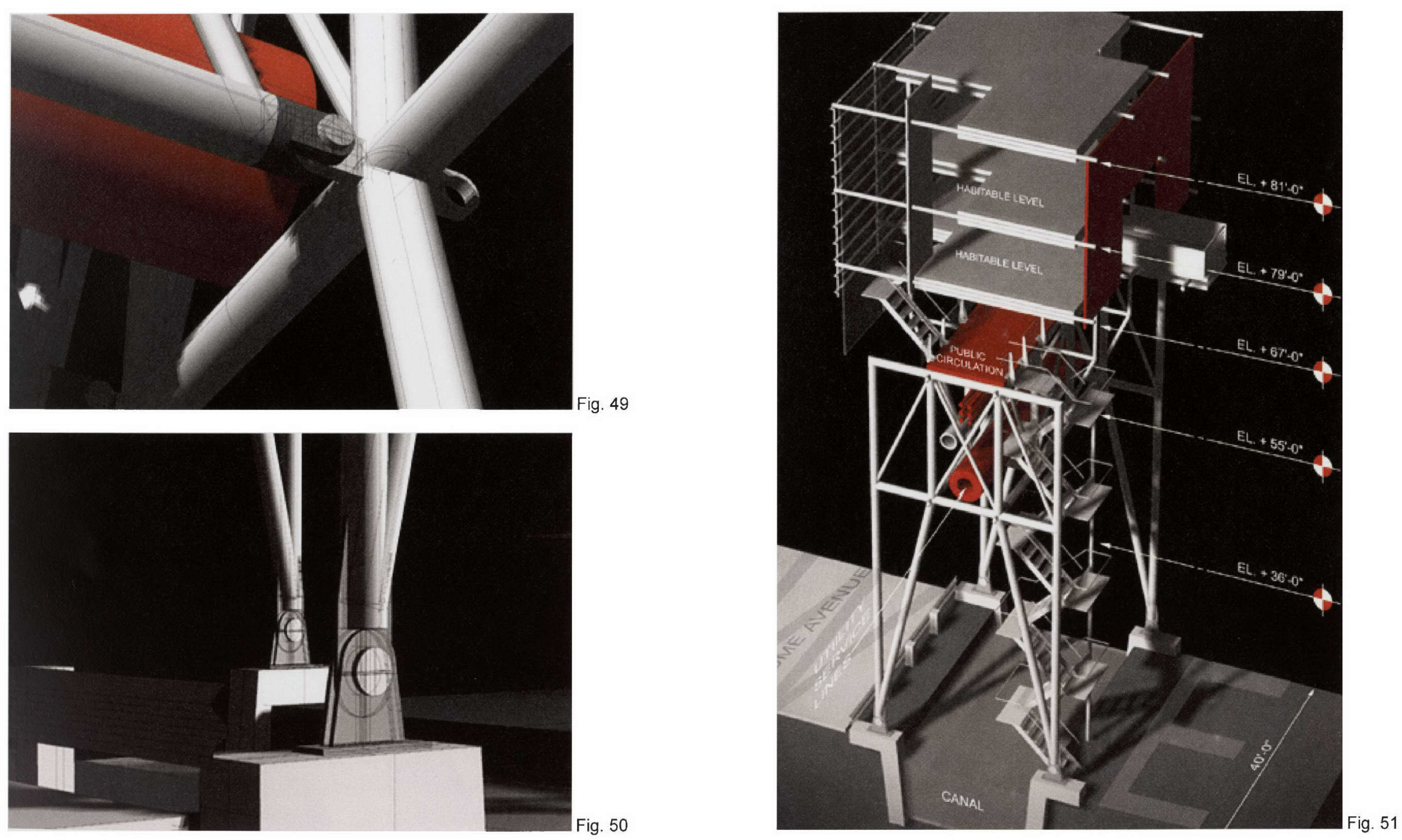

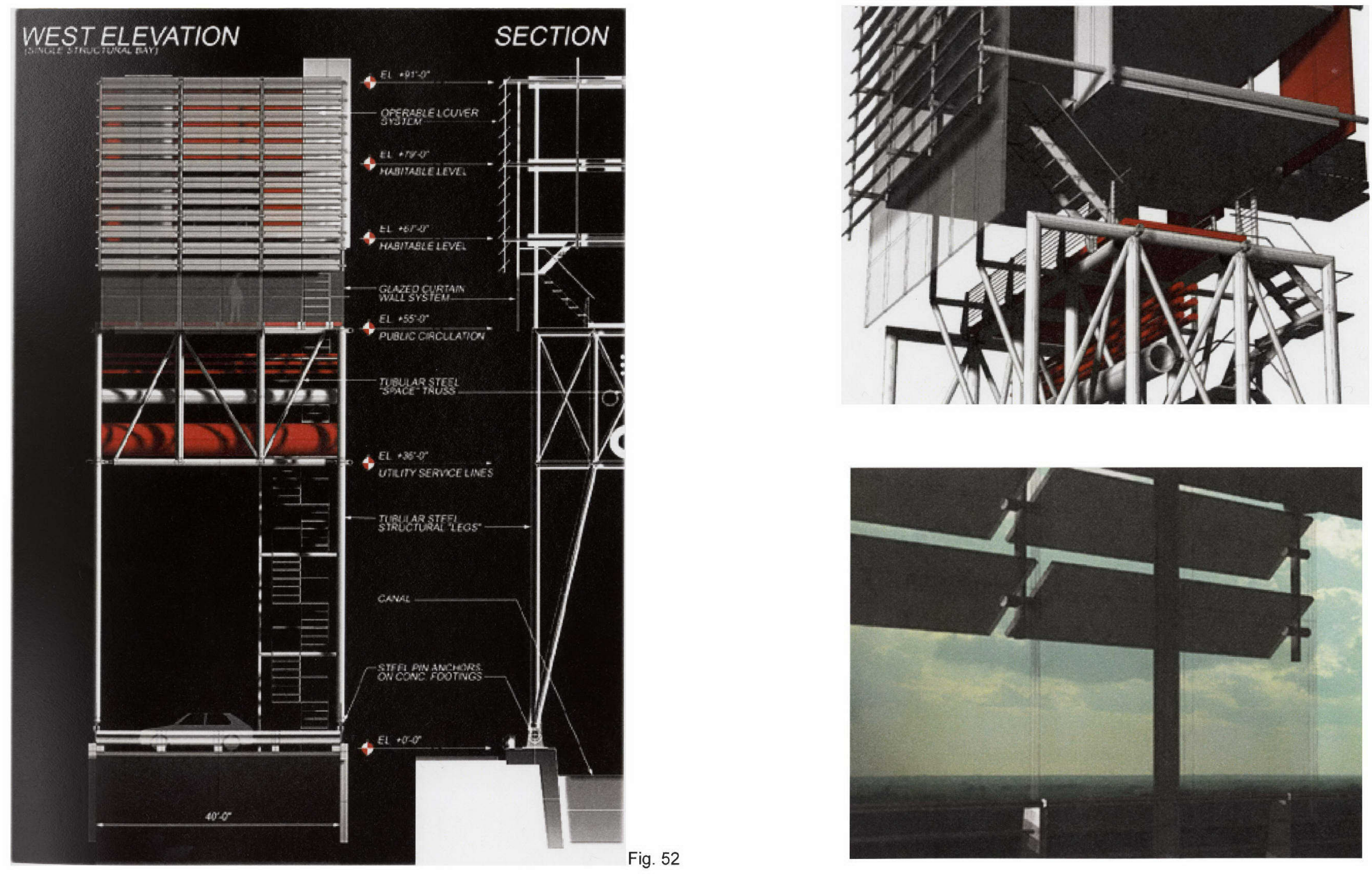

Fig. 53

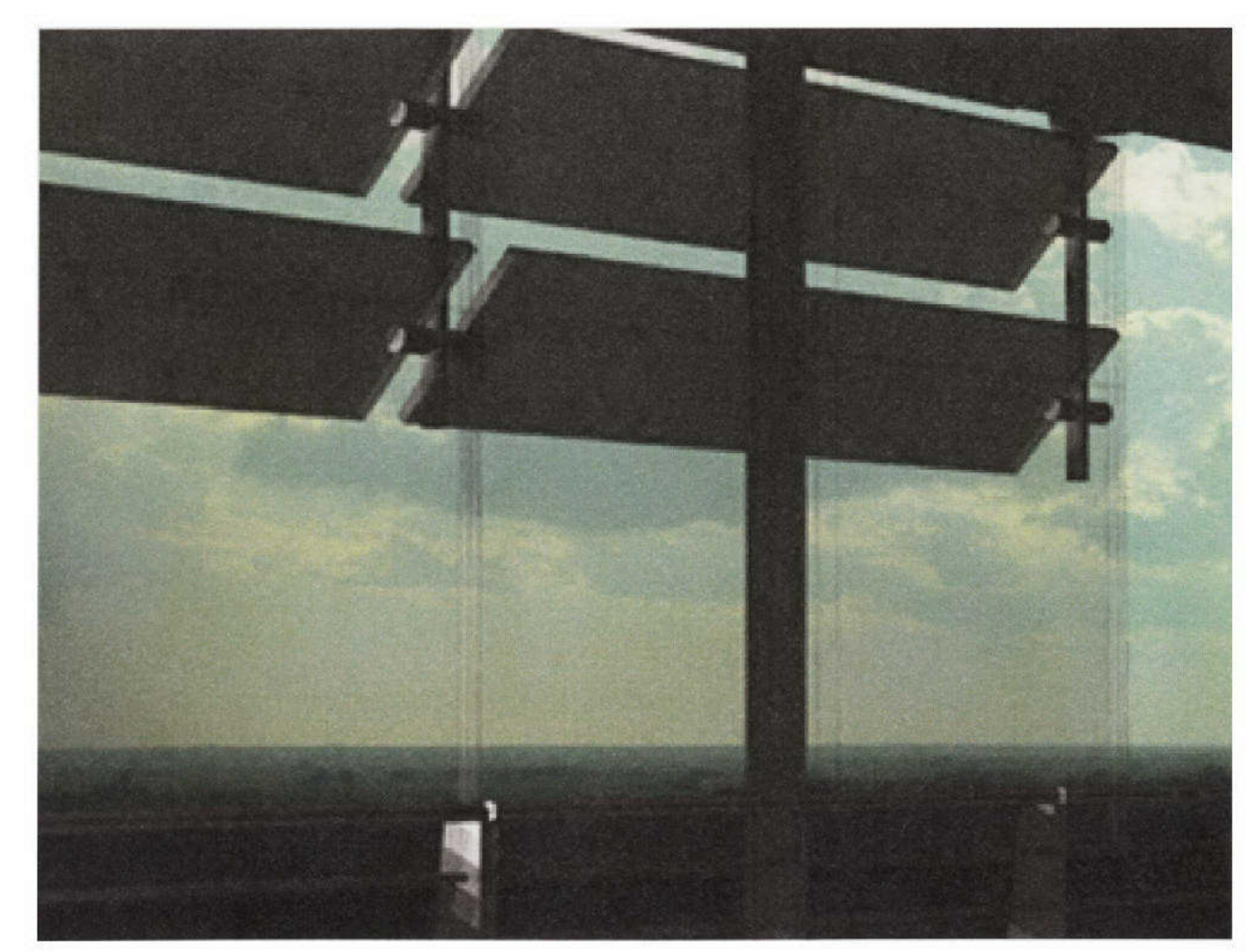



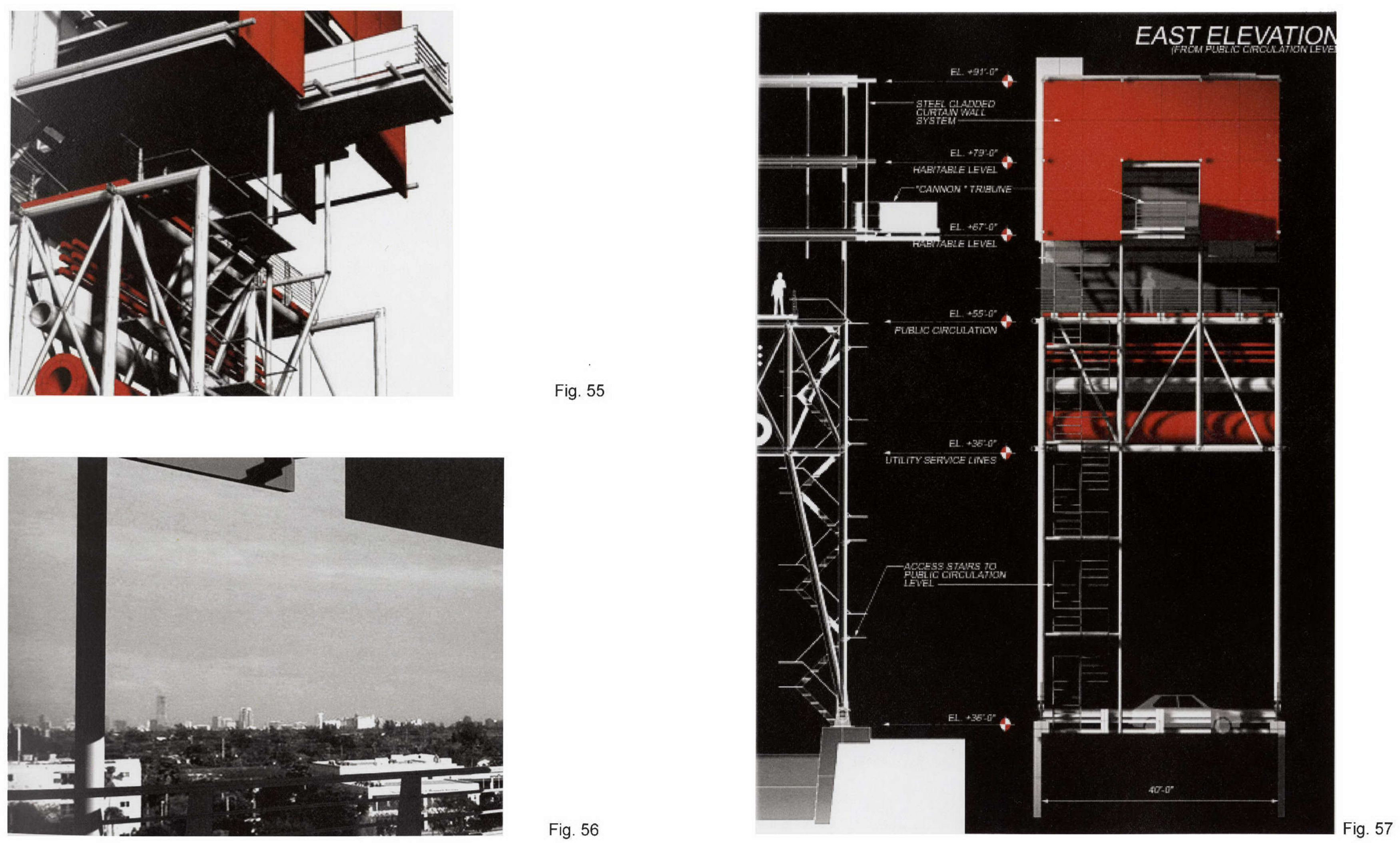


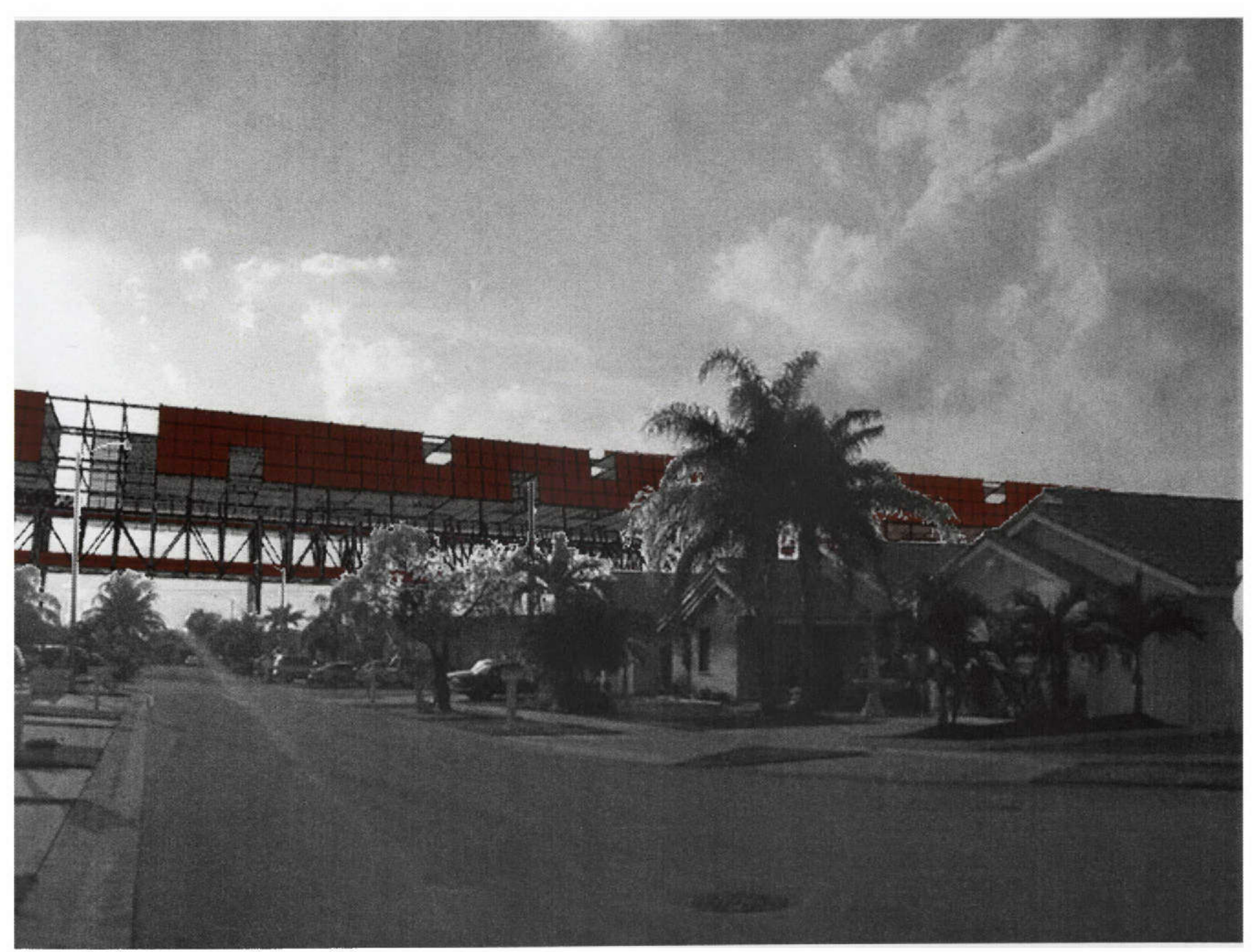

Fig. 58

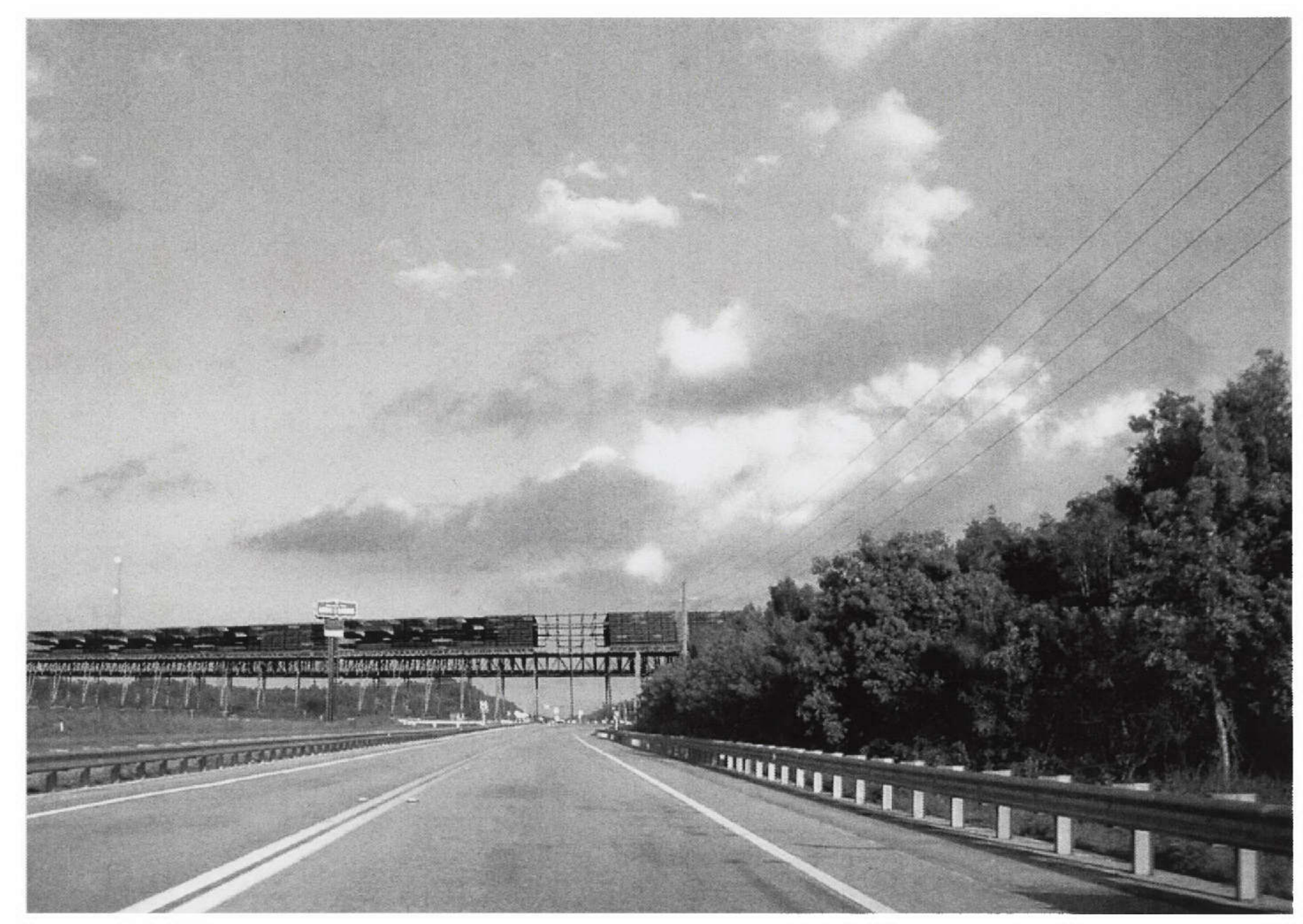

Fig. 59 


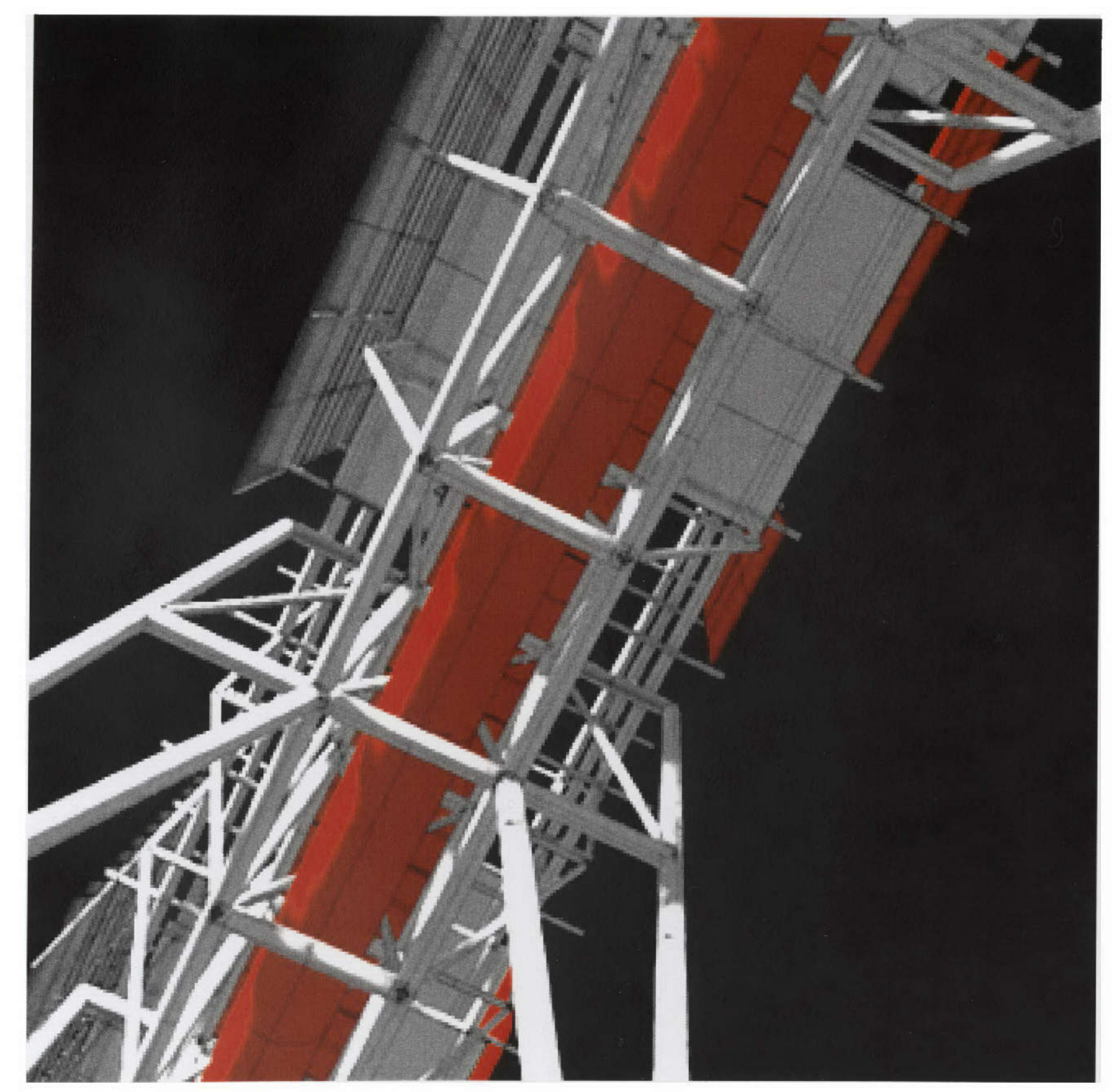

Fig. 60 


\section{List of References}

Beck, Haig, Rule Playing and the Ratbag Element: Denton Corker Marshall (Boston: Birkhauser, 2000)

Brice, Martin, Forts and Fortresses: From the Hillforts of Prehistory to Modern Times (New York: Quatro Publishing, 1990)

Correa, Charles, The Works of Charles Correa (New York: Thames \& Hudson, 1996)

Hogg, lan V., Fortress: A History Of Military Defense (New York: St. Martins Press, 1977)

Holl, Steven, Intertwining: Selected Projects 1989-1995 (New York : Princeton Architectural Press, 1996)

Jacobs, Allan B., Great Streets (Cambridge: The MIT Press, 1999)

Kostof, Spiro, The City Assembled: The Elements of Urban Form Through History (London: Bulfinch Press, 1996)

Laporte, Dominique G., Christo (New York: Pantheon Books, 1986)

Marsh, William M., Landscape Planning: Environmental Applications (Menlo Park: AddisonWessley Publishing Co., 1983)

Mc Cally, David, The Everglades, An Environmental History 1949-199 (Gainesville, University Press of Florida, 1999)

Mc Iver, Stuart B., True Tales of the Everglades (Miami: Florida Flair Books, 1989)

Metropolitan Dade County Office of Community and Economic Development, Historic Preservation Division, From Wilderness to Metropolis: The History and Architecture of Dade County, Florida, 1825-1940 (Miami: Metropolitan Dade-County, 1982)

Osborn, Fredric J., New Towns: Their Origins, Achievements and Progress (London: Leonard Hill, 1977)

Plutarch, Roman Questions, as cited in J. Rykwert, The Idea of a Town (Princeton: Princeton Architectural Press, 1976)

Scully, Vincent, Architecture: The Natural and the Manmade (New York: St. Martins Press, 1991)

Suárez, Sandra The One-Mile Square: A Collection of Space (Florida International University, 2000)
Suman, Daniel, Urban growth and Sustainable Habitats: case studies of policy conflicts in South Florida's coastal environment (Miami: Rosenstiel School of Marine and Atmospheric Science, University of Miami, 1995)

Toopes, Connie, The Florida Everglades (Stillwater: Voyageur Press, 1998)

Waterhouse, Alan, Boundaries of the City: The Architecture of Wetern Urbanism (Toronto: University of Toronto Press, 1993) 


\section{Endnotes}

${ }^{1}$ Kostof, Spiro, The City Assemble: The Elements of Urban Form Through History (London: Bulfinch Press, 1996), 12.

2 Plutarch, Roman Questions, as cited in J. Rykwert, The Idea of a Town (Princeton: Princeton Architectural Press, 1976), 28.

${ }^{3}$ Hogg, lan V., Fortress: A History Of Military Defense (New York: St. Martins Press, 1977), 13.

${ }^{4}$ Brice, Martin, Forts and Fortresses: From the Hiillforts of Prehistory to Modern Times (New York: Quatro Publishing, 1990), 10.

${ }^{5}$ Waterhouse, Alan, Boundaries of the City: The Architecture of Western Urbanism (Toronto: University of Toronto Press, 1993), 3.

${ }^{6}$ Holl, Steven, Intertwining: Selected Projects 1989-1995 (New York: Princeton Architectural Press, 1996), 24

${ }^{7}$ Hogg, lan V., Fortress: A History Of Military Defense (New York: St. Martins Press, 1977), 39.

${ }^{8}$ Holl, Steven, Intertwining: Selected Projects 1989-1995 (New York: Princeton Architectural Press, 1996), 143

${ }^{9}$ Kostof, Spiro, The City Assemble: The Elements of Urban Form Through History (London: Bulfinch Press, 1996), 29.

${ }^{10}$ Kostof, Spiro, The City Assemble: The Elements of Urban Form Through History (London: Bulfinch Press, 1996), 30.

${ }^{11}$ Holl, Steven, Intertwining: Selected Projects 1989-1995 (New York: Princeton Architectural Press, 1996), 148

12 Hogg, lan V., Fortress: A History Of Military Defense (New York: St. Martins Press, 1977), 41.

${ }^{15}$ Laporte, Dominique G., Christo (New York: Pantheon Books, 1986), 19.

${ }^{16}$ Mc Cally, David, The Everglades, An Environmental History 1949-199 (Gainesville, University Press of Florida, 1999), 83

${ }^{18}$ Mc Iver, Stuart B., True Tales of the Everglades (Miami : Florida Flair Books, 1989), 42

${ }^{19}$ Mc Cally, David, The Everglades, An Environmental History 1949-199 (Gainsville, University Press of Florida, 1999), 92
${ }^{20}$ Suman, Daniel, Urban growth and sustainable habitats: case studies of policy conflicts in South Florida's coastal environment (Miami: Rosenstiel School of Marine and Atmospheric Science, University of Miami, 1995), 141.

${ }^{21}$ Metropolitan Dade County Office of Community and Economic Development, Historic Preservation Division From Wilderness to Metropolis: The History and Architecture of Dade County, Florida, 1825-1940 (Miami: Metropolitan Dade-County, 1982), 67.

${ }^{22}$ Weisman, Brent Richards, Unconquered People: Florida's Seminole and Miccosukee Indians (Gainesville: University Press of Florida, 1999), 12.

${ }^{23}$ Laporte, Dominique G., Christo (New York: Pantheon Books, 1986), 22. 

Form Through History (London: Bulfinch Press,

Mc Cally, David, The Everglades, An Environmental History 1949-199 (Gainesville, University Press of Florida, 1996)

Laporte, Dominique G., Christo (New York: Pantheon Books 1999) 1986)

Kostof, Spiro, The City Assembled: The Elements of Urban Form Through History (London: Bulfinch Press, 1996)

Holl, Steven, Intertwining: Selected Projects 1989-1995 (New York : Princeton Architectural Press, 1996)

Kostof, Spiro, The City Assemble: The Elements of Urban Form Through History (London: Bulfinch Press, 1996)

By author.

By author.

Holl, Steven, Intertwining: Selected Projects 1989-1995 (New York : Princeton Architectural Press, 1996)

By author. Form Through History (London: Bulfinch Press,

Laporte, Dominique G., Christo (New York: Pantheon Books,

Brice, Martin, Forts and Fortresses: From the Hillforts of Prehistory to Modern Times (New York: Quatro New River canals, 1920-1927 (Digitized from Economic Development, Historic Preservation Division, From Wilderness to Metropolis: The History and Architecture of Dade County, Florida, 1825-

By author. 